\section{.8130}

\section{EINERGY}

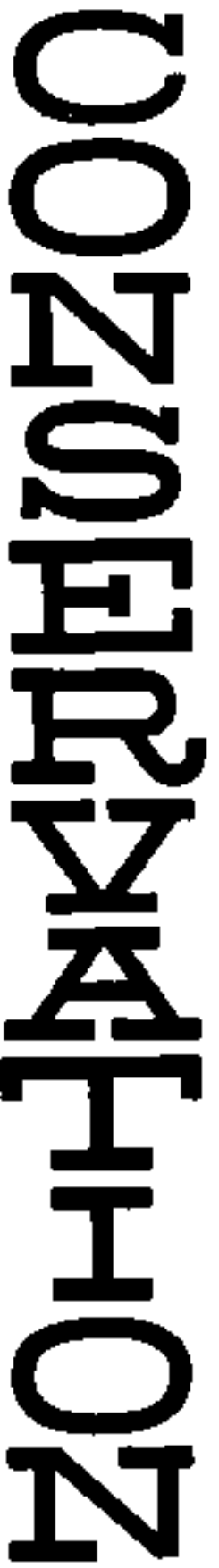

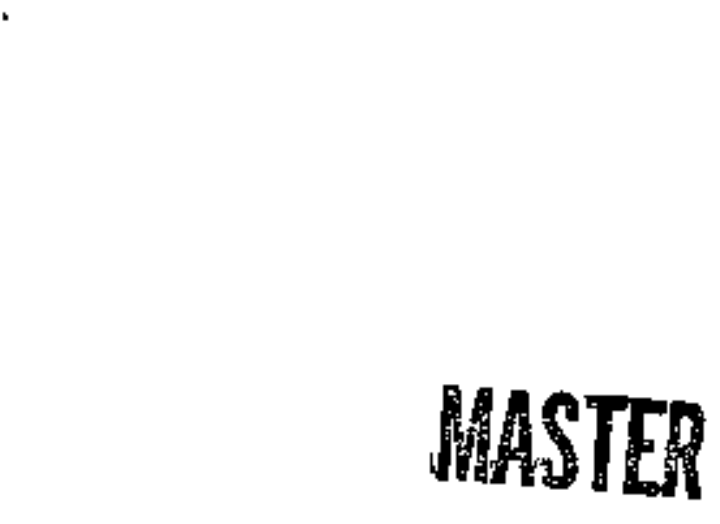

$+$

TRENTON ICES

Volume 1. Phase I, Fimal Report

$\cos / 4212-1 / 1^{-}$

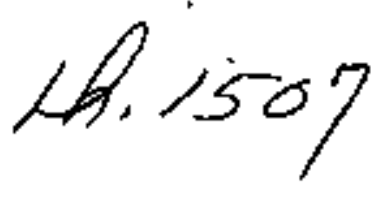

July 14, 1977

Work Performed Under Contract No. EC-77-C-02-4212

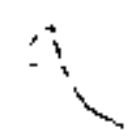

Department of Planning and Development City of Trenton

Trenton, New lersey

\title{
ENERGY RESEARCH AND DEVELOPMENT ADMINISTRATION .
}

Division of Buildings and Community Systems 


\section{DISCLAIMER}

This report was prepared as an account of work sponsored by an agency of the United States Government. Neither the United States Government nor any agency Thereot, nor any of their employees, makes any warranty, express or implied, or assumes any legal liability or responsibility for the accuracy, completeness, or usefulness of any information, apparatus, product, or process disclosed, or represents that its use would not infringe privately owned rights. Reference herein to any specific commercial product, process, or service by trade name, trademark, manufacturer, or otherwise does not necessarily constitute or imply its endorsement, recommendation, or favoring by the United States Government or any agency thereof. The views and opinions of authors expressed herein do not necessarlly state or reflect those of the United States Government or any agency thereof. 


\section{DISCLAIMER}

Portions of this document may be illegible in electronic image products. Images are produced from the best available original document. 


\section{NOTICE}

This neport was prepared as an account of wark sponsored by the United siates Government. Nefikes ibs Unlted States nor the United Stales Exergy Research and

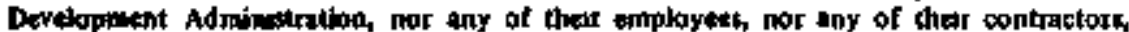
sobeontractors, or their employees, nakes any wirnty, express ar implied, ar asumes any kerl reflity or retpoesbility for the aceuracy, completeness or usefulness of iny Imformation, appapatus, product or process dlschsed, ar reptesente that its use would nat

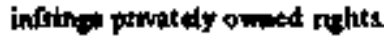

This report has been reproduced tirecty from the best ayailable copy.

Availsble from the National Technical Information Service, U.S. Department of Commerce, Springfield, Viginin 22161

$$
\begin{aligned}
& \text { Price: Paper Copy } 50 \text { (domestic) }
\end{aligned}
$$

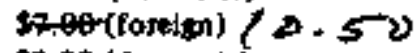

$$
\begin{aligned}
& \text { Microliche \$3.00 (domestic) } \\
& 54.50 \text { (foreisis) }
\end{aligned}
$$


Trenton ICES

Phase I Report - Volume 1

US ERDA Contrect $B C-77-C-02-4212$

The City of Trenton

Public Service Dlectric and cas Conpany

Richard G. Stein and Partners, Architects

Turner Construction Company

R. G. Vanderweil, Ingineers

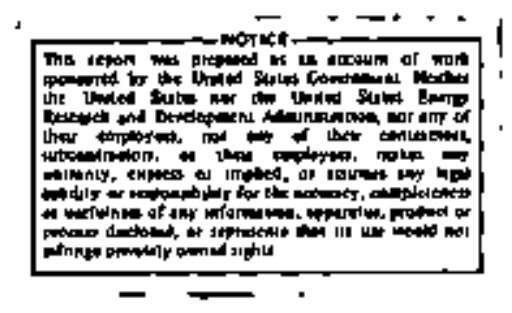

14 July 1977 


\section{ABSTRACT}

Fhase I Preliminary Desigm and Evaluation for a Grid Connected Thermally Controlled Integrated Community Energy System (ICES) for the city of Trenton, Hew Jersey has been carried out. The findings of the study are:

It is technically feasible, utilizing commercially atailable harduare.

It is economicelly competitive with conventional alternatives for heating and cooling buildings.

It will produce an overall reduction in fuel consumed of 32 to 43 percent when compered with conventional alternatives for heating and cooling buildings.

It will consume 4 to 9 percent more oil than will conventional alternatives for heating and cooling buildings.

It ahould be owned and operated by PSE \& G. No mojor institutionel impediments beve been discovered under this arrangement.

It can provide thermal energy 21 months after the start of Phase II and electrical energy 32 months efter the start of Phase II.

This study is site-specific and of a small size project. Its installation will not alter the planned PSE \& G capacity expansion progran. The econimic evaluation results of the report cannot be extrapolated for numerous co-generation installations that would affect the PSE $G$ plenned capecity expansion program.

On the basis of the above Indings, the members of the Phase I Demonstration Team for Trenton ICES anslysis are positively disposed toward procesding with the Fhase II design of the plant in order to conclusively test system fiability with the ultimate goal of plant construction. 
TABLE OF COHTENTS

Background . . . . . . . . . . . . . . . 3

Tesk I - Preliminary Bnergy Assessment . . . . 7

Task II - Institutional Asses sment . . . . . .21

Task III - Conceptual Design . . . . . . . . .27

Task $\Gamma$ - Fisming Up Commitments . . . . . . .51

Task $\mathrm{V}$ - Work Managenent Plan. . . . . . . .59 


\section{EACKCROUND}

The Trenton Integrated Community Energy System (ICES) study grous from the national concern to extract the greatest possible useful energy form each unit of scarce fual consumed. Modern large (thousand megatett) fossil fuel genereting plants have achieved efficiencies as hish as 40 perceat (useful energy output/fuel energy input). The remaining 60 percent of the heat produced by burning the ruel is released as thermal enexgy tuto the environment which serves as a low temperature sinis.

The Trenton ICES will generate electrict ty at lower efficiencies than the large central plant; however, a large portion of the heat discharged by the generating equipment will be captured and used for heating, cooling and domestic hot vater. The result of this is that the useful energy output from the ICES plant is about 63 percent of the fuel energy input, representing almost a doubling of fuel utilization.

The trenton ICss plant infls. into a general eategory referred to as co-generation, that is, thermal and electric energy are generated in one complex process! The heat produced by burning fuel is utilized at different temperatures for different uses. Mypically, co-generation plants are "electric-controlled," thet is, the output of the plant is besed on the demand for electrical fuergs, and the resulting lower teipersture heat is utilizeo to the degree to which there is a dengnd. Hovever, in most cases, wore vaste heat is produced then can be used and the excess "waste" heat is sirfily discharged to the atmosphere. 
The Trenton ICES plant is "thermal-controlled," thet is, the demand for thermal energy controls the output of the plant and, in turn, the quantity of electricsty produced. Since the system is connected to the utility electriesl prid, any electricity produced in excess of the demands of the community will be utilized by other customors In the rid, thereby asguring that the total "usenil" output of the plant is, in fact, serring some demand. This approech promotes an annual fuel utilization efficlency which much more closely approaches the pesk operating efficiency.

The Trenton ICES Phose I work hes identifled and modeled the every - charecteristica of the communty wich will place the thermal demand on the ICES system; evaluated the technological feasibility of such a plant; examined the 1nstitutional mechanisms required to budid and operate the plant; compared the economic and energy costs of the ICDS plent to those associated with "conventional" approsches to delivering the same services; furthor firmed commitinents from ICLS participants and regulating agencies; and proposed a work management plan to implement the ICES demonstration system.

This document aupmarizes the findings and conclusions of the Trenton ICES Fhase I atudy. The couplete results are found in volume II of this report. 


\section{task I}

\section{preliminary energy assessment}




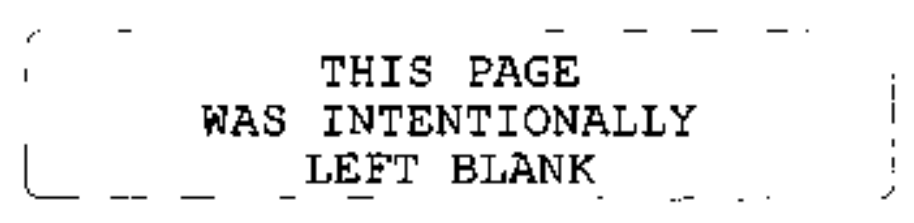




\subsection{SITE LAYOUT}

\section{Community}

The community served by the Trenton Integrated Community Bnergy System (ICES) plant is shown in Figures 1 and 12 . It is comprised of 1,884,025 square feet of floor area in existing buildings, and $1,251,500$ square feet floor area of new construction is projected for completion by 1982 . This results in a demonstration community of $3,135,525$ square feet floor area which the ICES will serve.

There are 18 existing buildings which would be served by the ICES plant. However, since these buildings share several common boiler plants, only four connections to the ICES plant are required. The longest of these connections is approximately 2,000 feet to the Statehouse complex. The total distribution distance to all existing buildings is approximately 3,400 feet.

DEMONSTRATION COMMUNTTY

\section{Existing Buildings \\ Kingsbury I Towers Kingsbury I Lowrise Mercer Co. Detention Center Mercer Co. Courthouse Labor and Industry Health and Agriculture Statehouse Complex \\ Proposed Buildings \\ Lutheran Arms \\ Capital Place \\ Capital Place Conmercial Justice Department Justice Commercial Firehouse \\ Kingsbury II \\ Civic Center \\ Dept of Env. Protection}

Total:

\section{SQ FT}

280,000

74,500

160,000

130,000

300,000

144,000

795,525

$1,884,025$

SQ FT Start Completion

$91,500 \quad 1977 \quad 1978$

$\begin{array}{lll}155,000 & 1977 & 1979\end{array}$

50,000 $1978 \quad 1979$

$\begin{array}{lll}350,000 & 1978 & 1979\end{array}$

$\begin{array}{lll}50,000 & 1978 & 1979\end{array}$

$5,000 \quad 1978 \quad 1979$

$200,000 \quad 1980 \quad 1981$

$100,000 \quad 1981 \quad 1982$

$250,000 \quad 1981 \quad 1982$

$1,251,500$

$3,135,525 \mathrm{SQ} F \mathrm{FT}$ 
State Building Complex

2 War Memorial

3 Civic Center

4 Department of Environmental Protection

5 Capital Place

6 ICES Plant and Parking

7 Courthouse and Detention Center

8 Luther Arms

9 Kingsbury 1 Highrise

10 Kingsbury 1 Lowrise

11. Kingsbury 2 Lowrise

12 Justice

13 Health and Agriculture

14 Labor and Industry

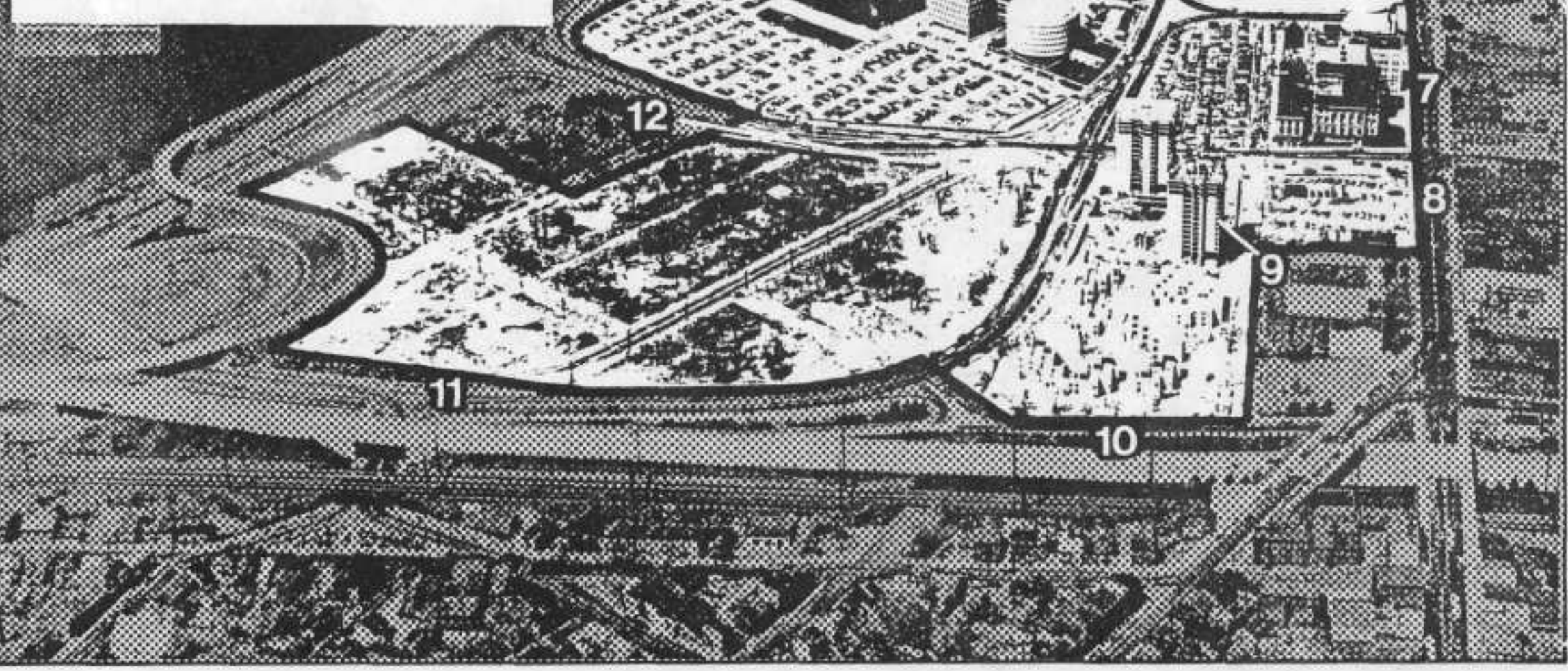


- Existing Sretems

A major criterion for the ICES System is to minimize disruption resulting from the connection of exdsting buildings to the systew.

Since the primary spproach includes electric supply by the existing utility, Public Service Blectric and Gas (PSE \& G) through its existing grid, the only existing systems which affect ICBS decisions are those with thermal demands. The statehouse Complex and the Lebor and Industry and Heslth and Agriculture buildings are served by boilers providing $125 \mathrm{psig}$ ateam. In order to permit direct connection to these buildings, an ICES system delivering 125 psig stesm was selected. The adoption of this epproach requires the provision of high temperature heat and therefore limints atrailable technologies. It was decided that since these building complexes represent 40 percent of the total Demonstration Comunity and additionally demonstrate the State's commitment to a congeneration approach, their inclusion represents a net benefit to the ICES project when weighed against the limitations inposed on the system.

\subsection{DEMAND PROFILES}

Three sets of hour-by-hour annual proflies vere developed for the ICES project. The f1rst of these is the thermal gain for the 15 builaings or groups of buildings which form the Demonstration Coumunity. This profile represents the thermodynamic performance of the buildings in response to exterior temperatures, solar gein, and interior heat sources other than the heating or cooling systems. It is this thermal gain (shown as a negative figure in the case of winter heat loss) which must be offset by the use of building heating or cooling systems. A grephic printout of a typical month is shown on Figure 2. A typical day within thet month has been expanded to indicete the hour-by-hour pattern.

The electric demand of the Demonstration Community was not modeled. This is because the entire electric output of the ICES plant is 
Senple

Building Thermal Gain

Profiles

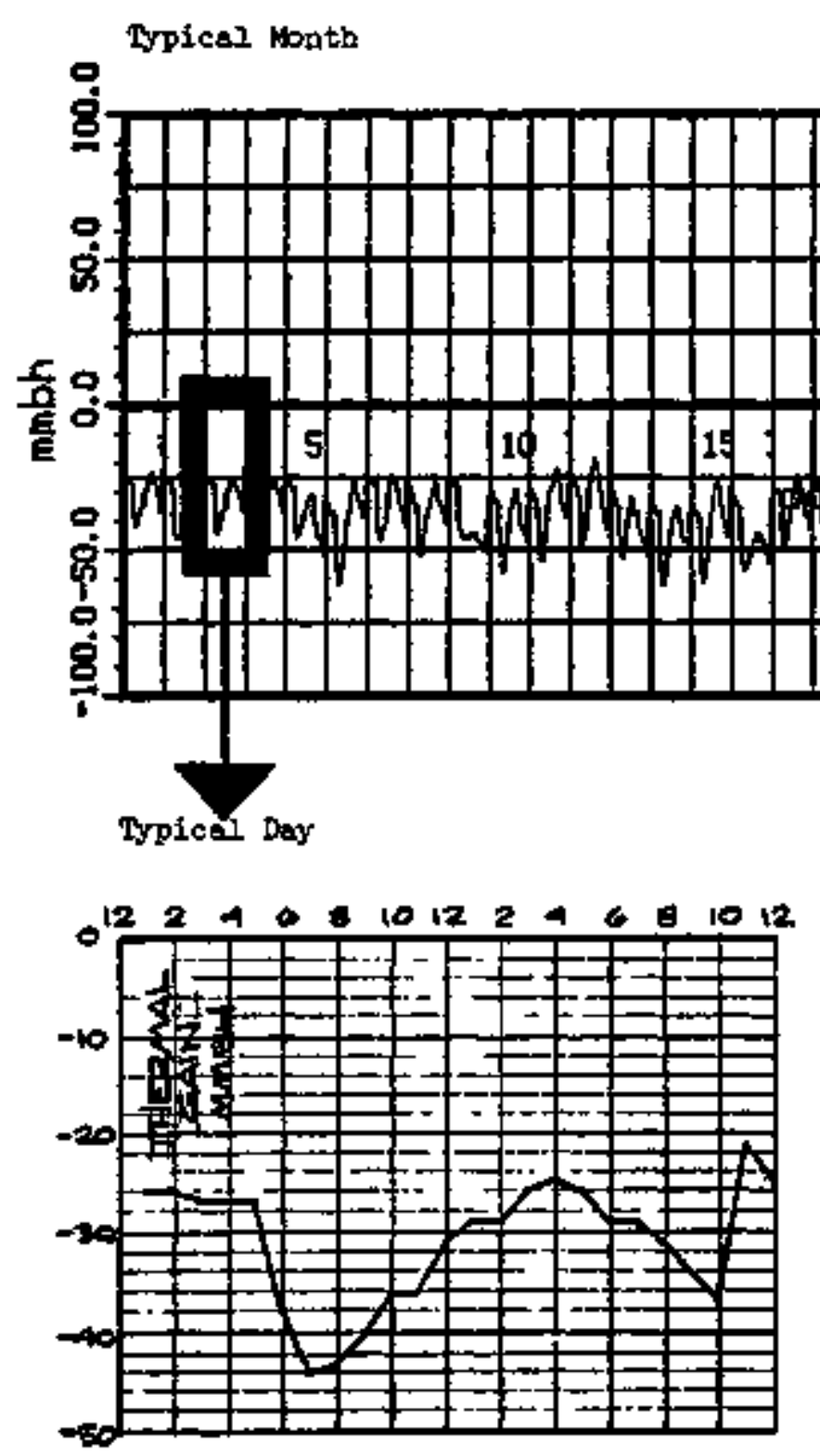


Sample

Building steam Demand

Profiles

Typlcal Honth
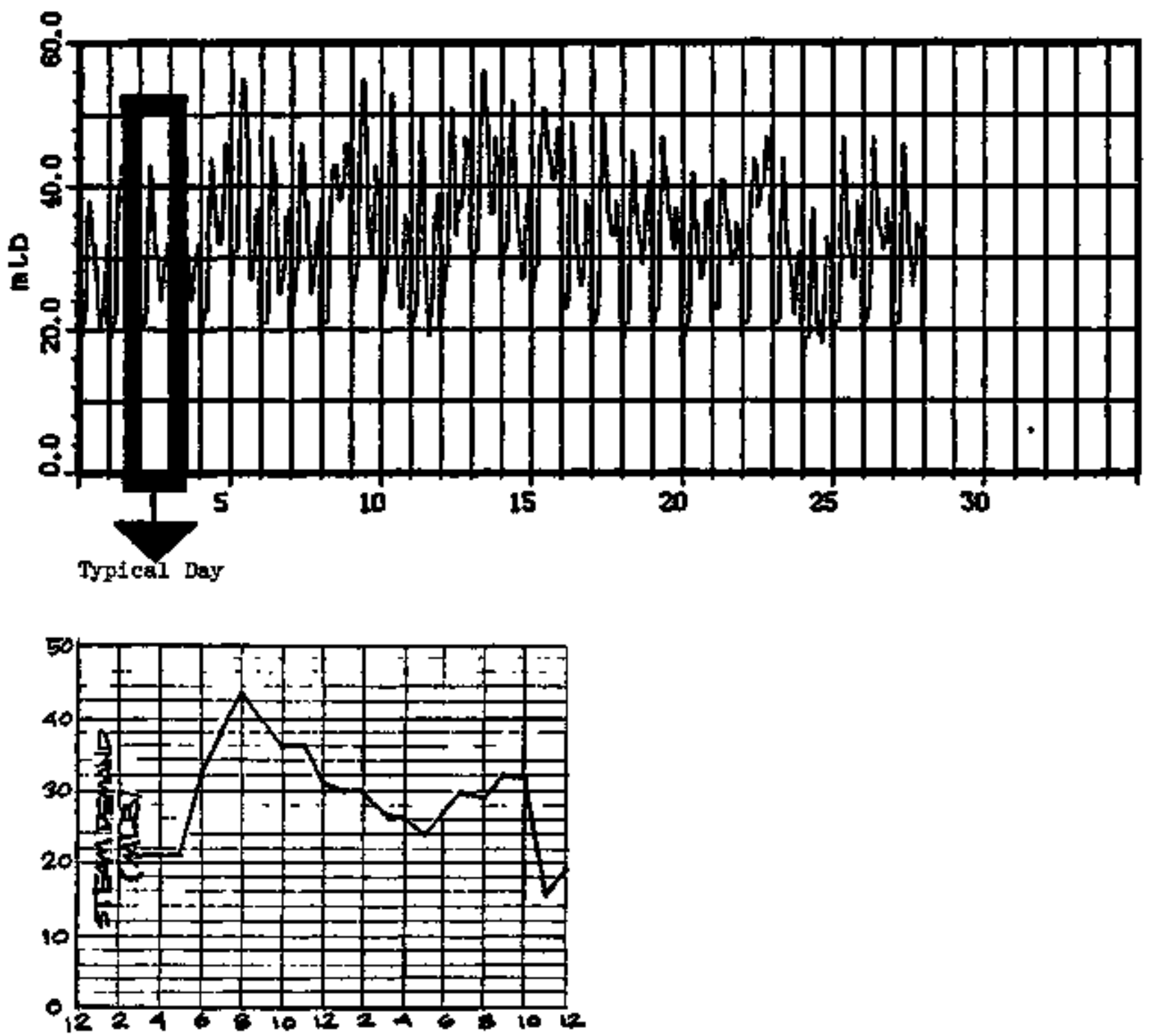
FIGURE 4

Senple

Buliding Electrical Generation

Profiles
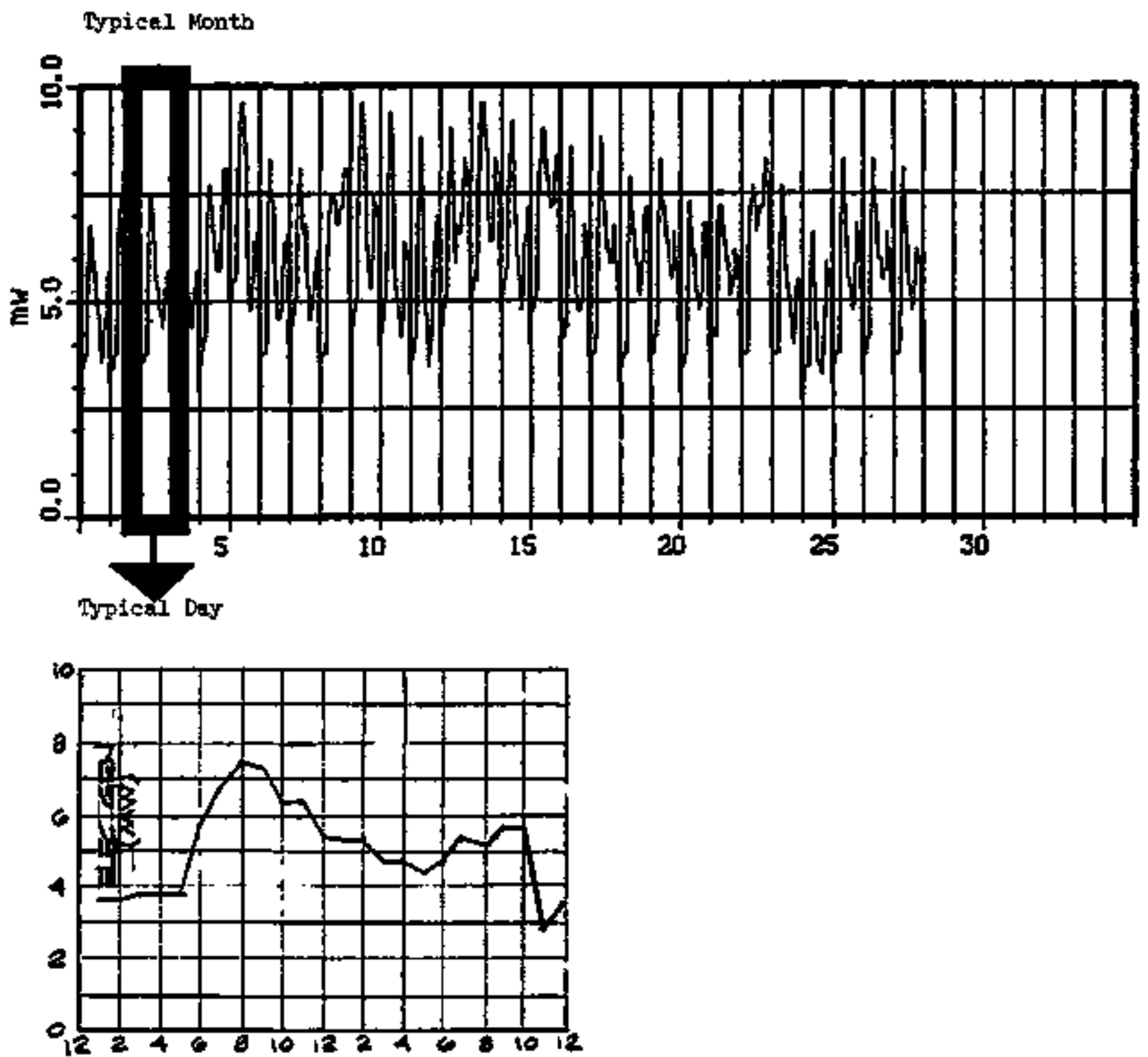
Th1s is because the ent1re electric output of the ICbs plant is fed into the PSE $G$ grid and the electric needs of the conmuity are served from this grid. Since the purpose of the analysis is to compare the ICES system with the conventionel system and since the 8 upply to the community of electrical energy is essentially the same in both cases, the simulation was not performed.

The thermal demand of the community provides the basis for the sizing of the ICBS plant.

The second is the community's demand for stean frow the ICES plant. This is the building heat gain characteristics as modified by thermal storage systems and by the performance characteristics of the absorption chillers which contert the steem into "cooling."

The third set of profiles is the electric output of the ICEs plant resulting from the demand for steam. This was necessary so that the energ and dollar value of the electric output of the ICES plant can be compared against that of a conventional system. The results of these simulations and the uses to whtch they trere put are described under Tesk 3.

\section{3 FROJECTED GROWTH}

The Fhase I feasibility analysis is based on an evaluation of the communty as it is projected in 1982. A reflnement of this analysis requires that the characteristics of the community prior to its reaching this size as well as with potential growth after' 1982 must be considered. A set of profiles for each signiflcant stage of development will be generated during Phase 2 .

It is not possible at this time to detail the post 1982 growth patterns; howerer, this situstion can be accomodeted in the besic ICES conceptual design in severel ways. 
* The distribution system can accommodate a 25 percent increase without modification.

* Adaitional radsal aistribution arms can be extended from the centrel plant.

* Space In the plant has been allowed for an additional turbine/ooller module.

* Space is provided in the existing module enclosures so that one or more of the 2.5 megawatt modules could be repleced with a 5 megawatt or 7.5 megrwatt unit.

* It is enticipated that much of the excitins Demonstration Coumunty will undertake enery conservation procedures in the next 10-year period. This reduction in demand from-the existins communt to will free capactty for an expanded service area.

\subsection{CONYEMTIONAL FNIMRG SYSTEM}

Two "conventional," thet is, nop-ICES aystems for the prorision of thermal energy to the demonstration commmity were evaluated. One system includes oil-fired boilers and electric chillers, the other uses electric heat pumps. These systems were subjected to the same type of analyses as the ICES.

The initial economde conslierations require the establishment of a methodology for comparing the ICEs to a conventional system. A "Total syaten" approach was utilized in which the overall annuni costs to the users are compared. The following items vere used ia the comparison.

\section{ICES}

1. ICaS Jnerg Production

(a) Capital

(b) Fuel

(c) Operatiog and Maintenance

2. "Reduced Flectricel Fnergr Demand (ICES versus Conventional)

3. "PSE \& G Replacement Energy and Capacity Credit

4. TPS \& $G$ Transmission and Distribution Sevings Credit

(a) Energ Ioss Reduction

(b) Eong Range Investment Savings

\section{Conventiongl System}

1. Steam Production
(a) Capitel
(b) Fuel
(c) Operating and Maintenance 
* It should be noted that under ICES, Items 2, 3, and 4 represent credits to this system. Item 2, reduced electrical energy, results from the fact that under ICES, new buildings utilize steam absorption chillers rether than electric chillers, thereby reducing their consumption of electric enersy.

Item 3, replacement energy and capacity, represents the value of the electric enery produced plus the value of the ICBS generating capecity to the PSE $\&$ system.

Item 4 represents the savings in energy and in capltel requirements for distribution equipment resulting from the proximity of the plant to the point of use.

The capital, fuel and replacement energy sections under ICES require that a considerably detailed study be done in oxder to determine with any degree of confidence the costs essocieted with these iteng. As these const1tute the major portion of the ICES operating costs, it was decided to postpone the economic analysis until the schematic design of the plant is completed and a simulation of a year's operation can be performed. This analysis is to be carried out as part of Task III, Conceptual Design.

\subsection{ICES CONDIDATE SYSTEN}

Based on commercial availability of hardware and the size of the plant, diesel and gas turbine technologies were considered for the generating equipment of the plant. of these, ges turbines were selected based on two factors. The rirst is that a large percertage of the weste heat frow the turbines is at relatively high temperatures ( $\$ 900$ degrees F,). since the plent must generate $150 \mathrm{psig}$ steam for compatibility with exlsting buildings in the Demonstration Community, this characteristic permits the capture of a substantially hi gher portion of the waste than would be possible with the diesel. The second characteristic of the gas turbine which makes it desirable for this application is 
the fact thet it will deliner 5.4 pourds of steam per net kllowatt hour as compared wth 1.3 pounds of steam per net kilowstt hour with the diesel, thereby satisfying thermal demand of the communty with a wuch smaller central plant. Since the plant is thermally controlled and will therefore have only seasonal operation, the minimization of capital cost is significant.

The heat recopery will be accomplithed with two stage boiler. The high temperature stage will produce the steam used for distribution to the community. A low temperature stage will generate 230 degree $F$. vater. A portion of this enersy will be used internelly in the plant for combustion air preheating and space heating. The remainder will be used for preheating condensate return in the steam system snd for hesting a tennis facility immedately adjacent to the ICES plant. The net thermal efficiency (excluding that thernal output which is used internally by the plant) is approximately 65 percent. The cycle is ghown on Figure 5.

\subsection{THEFMAI DISTRIBUTIOH}

Thermal distribution wil be carried out delivering 125 psig steam for compatibility with existing terminal equipment in the gtatehouse, Healtb/Agriculture and Labor/Industry complexes. Buildings will be provided with heat exchangers to permit the conversion of the dell vered steam to a form compatible with the local heating end hot water systems. Exfsting buildings will utilize the chlllers which are presently installed. Hew buildings will be provided with twostage absorption chlllers, permitting the arrect use of the $125 \mathrm{psig}$ steam for the production of chilled water.

The distribution system is described in detail in section III. 


\section{PROPOSEO ICES PLANT CYCLE AT WINTER DESIGN CONDITLONS}

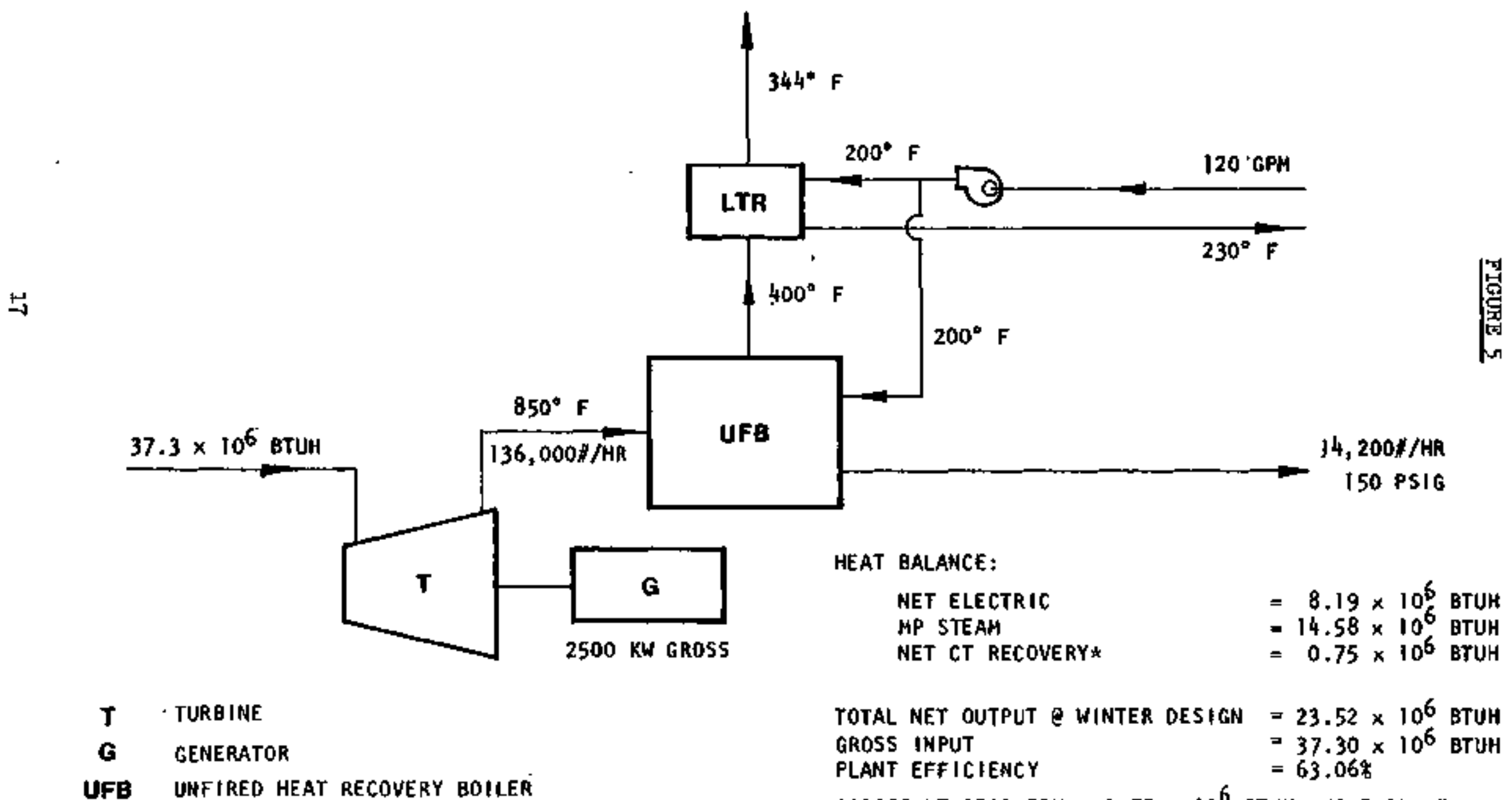

.GROSS LT RECOVERY $=2.75 \times 10^{6}$ BTUH. HOWEVER AT WIATER DESHGN CONDITION, COMEUSTION AIR PREHEAT REQU IRES APPROXIMATELY $2.00 \times 10^{6}$ BTUH 


\subsection{THERHAL STORAGE}

Thernal storage will be insulated steel tanks buried adjacent to the ouilings or terminal equipment which they service. They will store heated water during the winter and chilled water during the aumer.

The installed cost for the storage system is estimated at $\$ 590,000$ in 1977 dollars. The inclusion of this storage permits the plant to extit uth one fewer senerator/boiler module tban would otherwise be the case.

The four-module plant is estimated at $\$ 6.6$ millon in 1977 dollars. On this basis the inclusion of the thermel storage fecility reduces the central plent cost by wore then $\$ 1$ million.

The approach chosen for thermal storage has several distinct advantages over any athers. The components are readily available and are used in contentional fastion, facilitiating installation and mintenance. The fact that storage is at the terminal rather than at the supply reduces the peak demand on the distribution system es well as on the generation equipment which, in turn, permits both of these systems to be reduced in size. In adation, the storage falls between the points of end use and the chillers which also reduces the size. requirement for these units. While the intilal decision to utilize remote thermal storage was based on a comparison between the cost of the thermal storage and the central plant equipment, its use also reduces distribution and terminal requirements which, in turn, show added benerits to ICES.

\subsection{BEECTRIC POWLR DISTRIBUTIOH}

The Trenton ICEs described in this report is besed on PSE 4 G ownership and on the supply of electrictity to the Demonstration Community from the PSE \& G grid. Since electrical distribution remains unchanged in the ICBS or conventional approaches, no special ICES electricel distribution system has been developed. 
task II

institutional assessment 
THIS PAGE

WAS INTENTIONALIY

LEFT BLANK 


\subsection{IHSTITUTIONAL ASSESEMENT}

Three categories of institutional quegtions affecting the ICES plant were analyzed. These vere: Legel and regulatory considerations controlling the plant regardless of ownership; Legal and regulatory considerations unique to each ownership option; and general acceptance of plant by its potential users and by the public at large.

\subsection{GENTRAL CONSIDEFATIONS}

\section{Bnvironaient}

The effect of the Trenton ICES plant on the surrounding environment falls within the control of the New Jersey Department of Environmental Protection and the City of Trenton. The primary areas of environmental concern are: chencal and perticulate discharge to the atmosphere and to surrounding weter and the creation of notse.

In the case of the 'Trenton ICES, water pollution is not expected to pose any problem. There is no connection between the plant and any of the adjacent naturel water systems. An initial review of the operation of the plant indicates that its discharge to the atmosphere can be kept within present Department of Environmental Frotection Standards and that noise can be held to acceptable levels.

\section{Het Jerser Public Utility Commission}

The Hew Jeraey Public Jtility Comfission (PUC) will have Jurisdiction over the operation of the ICES plant regardless of ownership. The basic areas of PUC responsibility will be frenchise approval of steam arstribution (in the case of Public Service Electric and Ges ownership); electrical franchise territorial acquisition (in the case of musicipal ornership); control of stocks, bonds, notes, etc.; and control of the general operation and adminiatration of the plant once it is in service (in the case of either form of omership). 


\section{Federel Power Commission}

Federal Power Conmission Jurisdiction will apply besed on the fact thet the ICDs plent, regardless of ownership, will be connected to the PSE \& $G$ grid and there will be energ interchange between them.

\subsection{FUBLIC SERVICE BLECTRIC ARD GAS COMPANY (PSE \& G) OWNERSHIP AND OPERATIOH}

There are no fundsmental restrictiong which would prohibit PSE \& $G$ fron orming and operating the Trenton/ICES plant. The selling of steam is within the scope of PSE \& G charter and no Ner Jersey laws or ordinences heve been whcovered which would prohibit this activity. The question of the sbility to refuse certain prospective steam customers due to plant and distribution limitations requires further study. Rate structuring is a matter for PUC review.

Other institutional questions analyzed for Public Service Electric and Gas ornership are zoning; the fact that the ICES site is in a designated urban renewal aree; labor errangements for plant construction and operation; taxation and rinance; and the method of determining steam rates. In all of these issues there appear no unusual problems relating to ICES.

\subsection{CITY OF TREDTON OWNERSHIP}

Municipal ownership of the ICES plant was analyzed to determine whether any fundamental impodiments existed to this approach. The state laws of New Jersey clearly permit municipal ut1lities; however, the decision as to whether the profect should be undertaken would be subject to public referendum. Wunicipal ownership was further complicated by the intertining of its services with those of Public service Electric and Gas in the center eity of Trenton. 
Coning questions are somewhat simplified as the muricipality is not bound by local regulations; however, the impact of the urban renewel requirements remaln the same for either omership option. The operating labor arrangements may be complicated under nunicipal owner. ship, depending on whether plant operation is handled by contract for service or by civil service employees. The ICES plant would be tax exemp; however, it would elso result in a loss of tax reventse to the city.

\subsection{JOINT TRENTON/PSE \& G OWISERSIP}

The general concept of joint private/municipal omership was reviewed for institutional feasibjlity. Although no legal or regulatory restritetions were uncovered which wowd preclude such en errengement, their remain some fundementel administretive and institutional difficulties which must be overcome to institute such an arrangenent.

\subsection{PUBLIC INFORMATION PROGRAM}

The ICES Team has actively worked to gatn support for the plant from potential customerg and the commity at large throughout the first phase of the project. Efforts in this area have included public meetings arranged by the City of Trenton Department of Planning and Development involting the Demonstration Tean and potential customers end public agencies, press releases and updates to local news media, appearances at expositions and civic metings, end the preparation of an explanatory brochure describling the concept and benefits of the ICES system. This brochure has been mailed to environmentel groups, labor unions, politicians, members of the business communtty, civil servants, professional and trade essociations and citizens groups.

The ICES team anticipates continuing strong efforts to obtain public atrareness of the program, culminating in the creation of an energy information center as an integral part of the ICES plant (see Section III for detajls). 
WAS INTENTIONALIY

LEET BLANK 
task III

conceptual design 


\section{THIS PAGE \\ WAS INTENTIONALLY \\ LEET BLANK}




\subsection{ICES SYSTEM}

\section{ICES Plant}

The Conceptual Design of the ICES plant is based on the considerations outlined under Task 1 . The primary generation technology is combustion turbine with the exhaust passing through unfired heat recovery boilers. These are two-stage bollers with the first (high temperature) stage, generating $150 \mathrm{psig}$ steam and the second stage, producing 230-degree hot water. An auxiliary boiler provides thermal stand-by reserve equal to the output of two turbine/heat recovery boiler modules.

The basic module is a 2.5 megawatt gas turbine/generator set with a capacity to satisfy approximately 25 percent of the peak thermal demand. Four modules are provided. Redundancy and exceptional peak capacity are provided by the auxiliary boiler. This configuration permits a large degree of operational and expansion flexibility. The ability to function on fewer than four turbine/generator sets permits plant operation at less than peak demand while maintaining a high plant efficiency due to the heavy loading on those pieces of equipment which remain in operation.

The enclosure for the ICES plant is integrated into a parking garage for 1,200 vehicles to service the Capital Place Complex with capacity for Labor and Industry, Health and Agriculture, the Detention Center and commercial buildings adjacent to the Demonstration Community.

In addition, the ICES plant will serve a proposed Civic Center, primarily in the evenings. In order to facilitate pedestrian movement from the garage to these places, an elevated sidewalk system to the adjacent sites is provided. This system may allow the thermal distribution from the ICES plant to these adjacent sites to be run in chases provided beneath these walkways, thereby minimizing the excavation of public streets and facilitating future maintenance. 


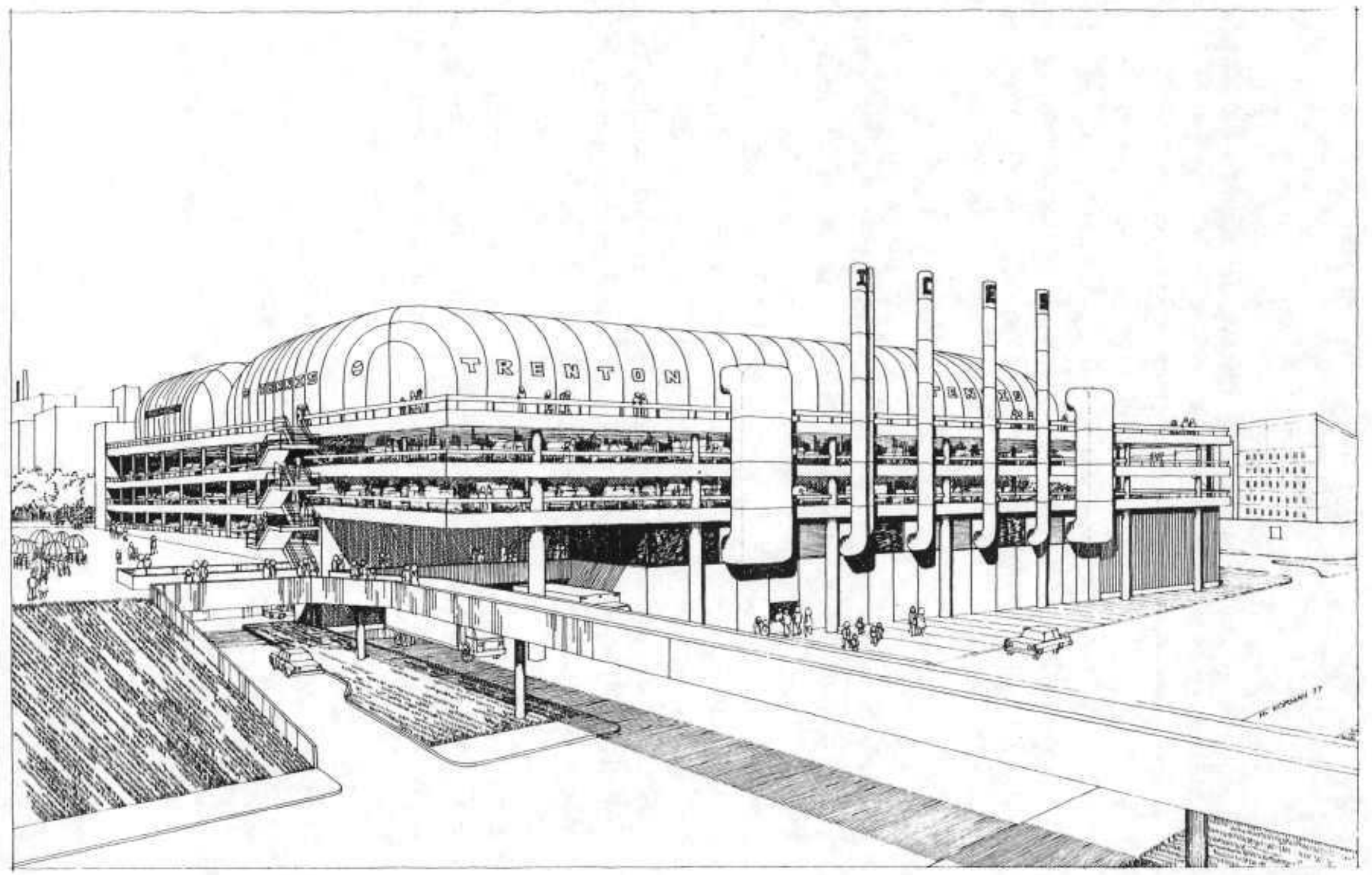




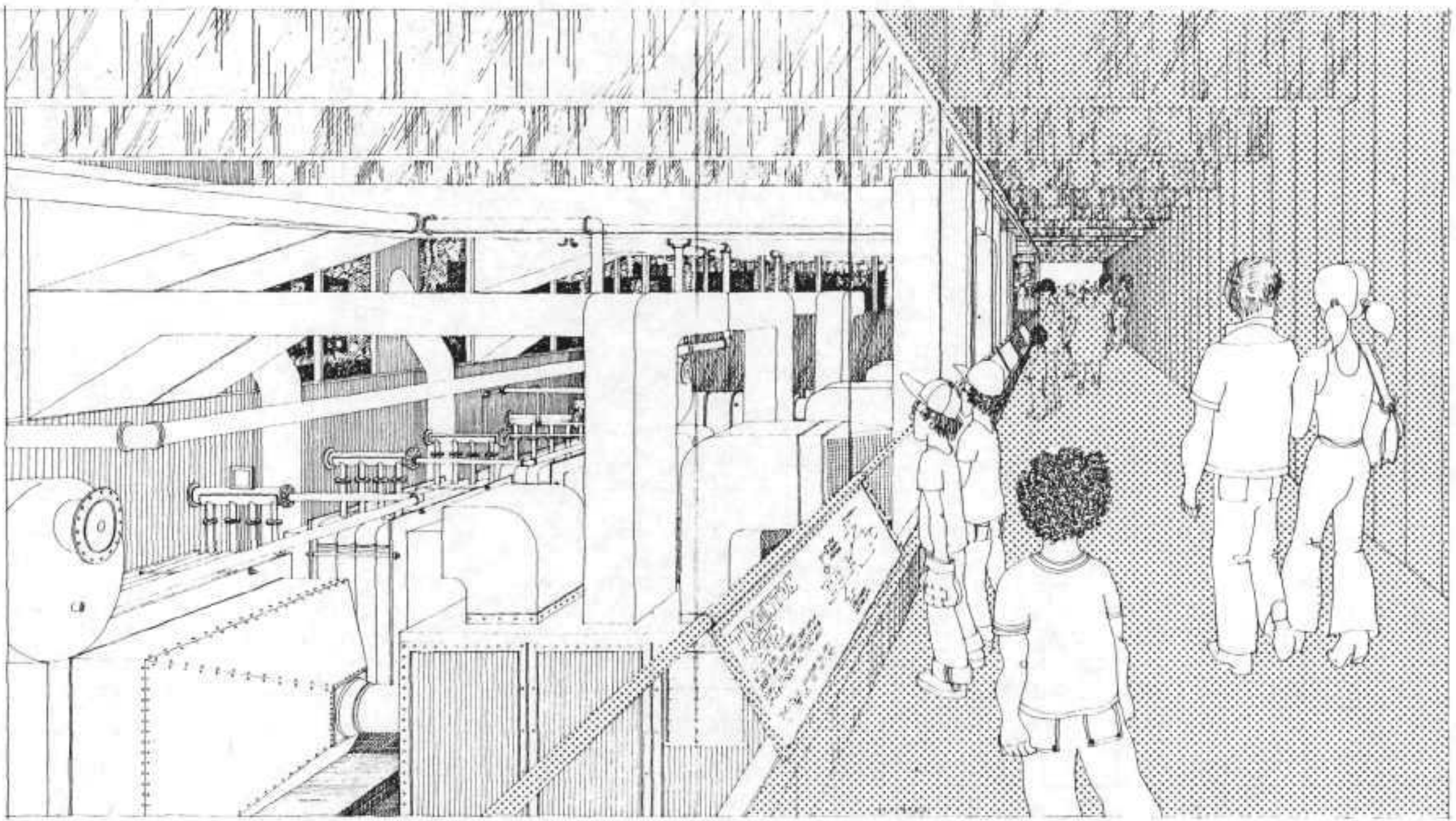


ICES PLANT \& DISTRIBUTION SCHEMATIC

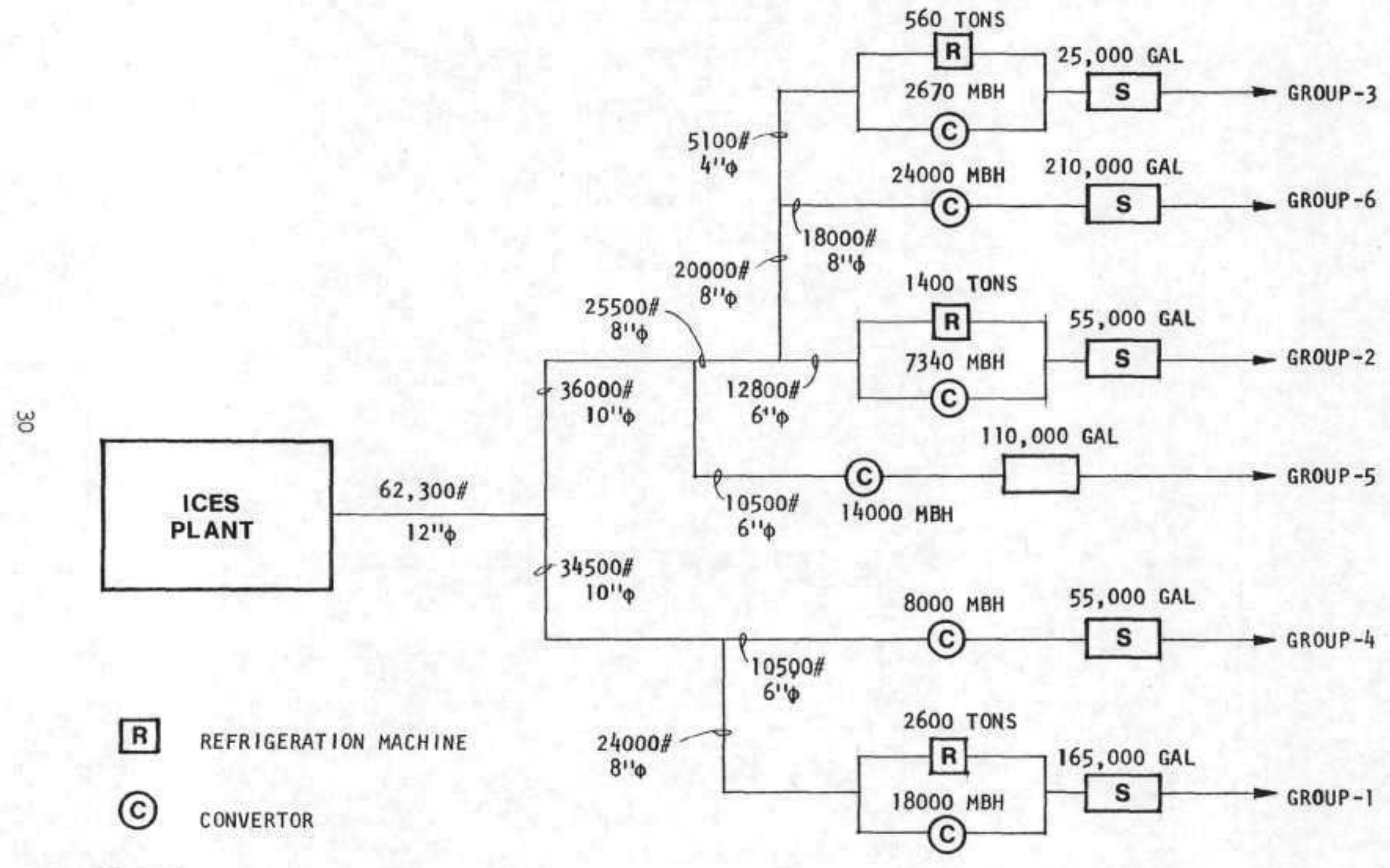

S StORAGE TANK 
GROUP-1: C E C SCHEMATIC

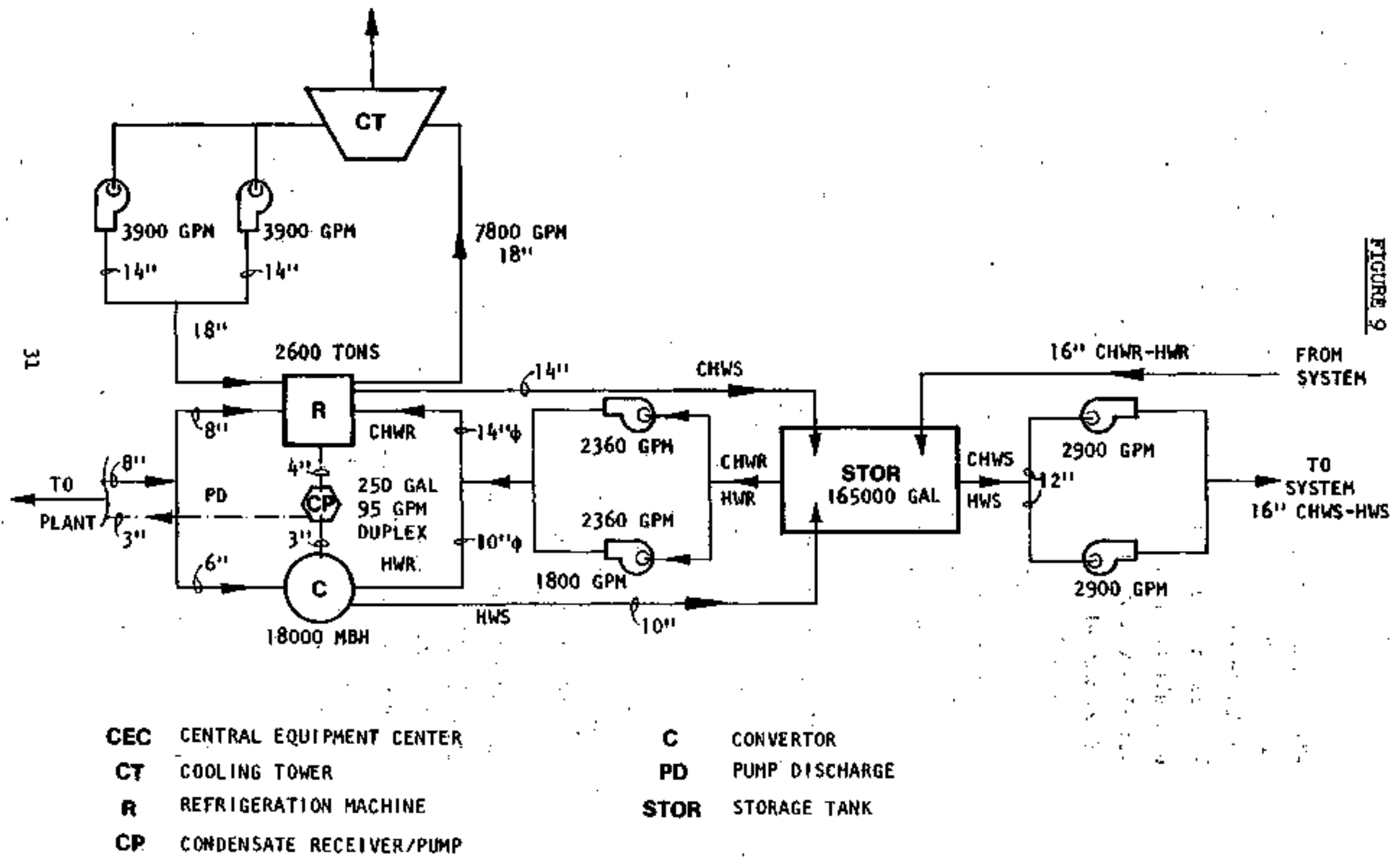




\section{Bnerar Information Center}

An additional benefit resulting from the placement of the ICBS plant in the center of an intensively used efrculation route is that it will serve as an "Energy Information Center." The ICES plant will be a highly visible bullaing in Tronton, the New Jersey State Capital. The eleveted sidevalk and the ICES plant will be separated by a wall of ecoustical glass. The equipwent will be color coded. Explanatory plaques and diagrams along the sidevalks will explein the function of the plant equipment as well as the basic concepts of ICES. Display cabinets and panels vil house energy-related exhibits and informetion describing energ conservation techniques. Graphic material describing the ICBS plant is included in Figures 6 through 9 and 12 through 20 .

\section{Thermal Distribution}

The basic distribution system consists of primary $150 \mathrm{palg}$ steam distributions to six central equipment centers which utilize the steam to produce hot water for heating, domestic and process use, reduced pressure steam for process use, and chilled water for spece cooling. Eech central equipment center will contain steam-hot water converters, two-stage absorption chillers, condensate receivers/pumps, cooling towers, pumps and auxdliary equipant and storage capacity.

\subsection{EHERGY AHD COST AHALYSES}

\section{Capital Costs}

The preliminary estinate of the cost of the complete ICRS system besed on the design described above and the equipment is $\$ 8,038,800$ In 1977 dollars and exclusive of normal construction overhend, profit, and contingencies and Bngineering fees. With these items added, the total cost of the ICES system becomes $\$ 11,138,800$.

The cost of the central ICES plant inclualng heat recorery equipment ia $\$ 6,655,100$. 
The eost of the distribution system is $\$ 1,464,700$.

The coat of the terminal equipment at the butldings being served by ICES is $\$ 3,019,000$.

\section{Fupl Input versus Eneror Output}

In order to complete the econoric evaluation of ICES, a ruel input/ energy output anazysis was developed. This was simulated on en hour-by-hour basig for a typical year.

For the year simulated, the oil consumption for the ICES plant is 73,364 barrels, the total electrical output is 28,079 megawatt hours, and the net 8 team output is $176,822,000$ pounds.

The simulation identifies whether the electricity is produced during on-peak or off-pesk hours, and the value assigmed to the electricity is based on the time-ofrang of production.

\section{Other Costs}

Operation and mainteriance costs are assigned to ICES based on the Utility's experfence and on a careful analysis of the type of staff and nafntenance procedures requered by this particular installation. Credits are asgigned to the capital ralue of the ICEs plant to the ttility.

Similar analyses were performed for conventional supply of thermal energy using ol1-flred botlers in one case and electric driven heat pumps in another.

\section{Economic Analysis}

A "total system" approach was applied in wich the total costs of the ICES were compered to those of a conventional system. The costs for the ICES and conventional system follor: 


\section{ICES Costs}

1. Those costs associated wh the total ICDS eneray production including saptal, fuel, operating and mintenance.

2. The savings associated with supplying less electric energy required by the community, as compared to the conventional system, at the spplicable rates.

3. A credit for the value to PSE \& $G$ of the energy and cepecity provided by the ICES plant

4. A credit for PSE \& 6 transigission and datribution long-term sarings resulting from the generation of the ICES plant.

Conventional Syatem Costs

1. The costs associated with the conventional heating facilities to provide steem output equivalent to that of ICES, including capital, fuel, operating and maintenance.

The ICES cost and the conventional system cost were then compared on the basis of "present worth of all future annual revenue requirements." It may be pointed out that a "zero" bottom liae indicates that the ICES would be profitable.

The ICES shows a competitive economic position compared to both conventional alternatives. The Phase I anelysis shows a marginel annual penalty to ICEs of $\$ 100,000$ as compared with the oil-fired conventional system, and $\$ 260,000$ es compared vith the electric heat purf conventional aystem viewed in 1982 dollars. Based on a 1982. capital ralue of $\$ 14,215,000$ these differences are lesa than the anticipated error in this preliminary economic evaluation. This 
analysis also assumes that all. the costs of the system are borne by the ICES owner and customers. In fact, ERDA funding support of Phase II alone vould be equivalent to a reduction of the ICES annualized cost of approximately $\$ 100,000$ per year.

\section{Fuel Analysis}

The analysis of fuel use made for the economic evaluation also pernits the following energy compartion for the three approaches.

The ICES system requires a total annual fuel input of 73,364 barrels of ofl (425.5 $\left.\times 10^{9} \mathrm{Btu}\right)$ to produce 1 ts total electric and thermal output.

The conventional system, using oil-fired boilers, requires an annual input of 40,975 barrels of oil (243.5 $\times 10^{9}$ Btu) for the provision of thermal energy alone. This thermal energy is somewhat legs than the thermal output of the ICES plant due to the use of electric vapor chilzers. Based on PSE \& $G^{\dagger} s$ present and projected generation mix, incremental electricity during on-peak hours will be produced by all-fired plants and during off-peak hours will be produced by coalfired plants. The simulation of the community demand for the conrentional system using oil-ifred boflers permits the identification of on-peak and off-peak usage. Based on the above, the annual fuel use due to this electrical production is 27,779 barrels of oil (166.7 $\times 10^{9}$ Btu) plus 6,440 tons of coal (27,903 equivalent barrels of oil or $167.4 \times 10^{9} \mathrm{Btu}$ ). In other words, the total oil input for the conventional system with ofl-fired heating to provide the equivalent output of ICES is 68,754 barrels of ofl plus 6,440 tons of coal or a total of 96,657 equivalent barrels of oil or $579 \times 10^{9}$ Btu.

Based on the seme methodology, the conventional system using electric neat pumps in the proposed buildings shows a total annual fuel use of 32,002 barrels of $011\left(194.6 \times 10^{9}\right.$ Btu for the proviston of thermal energy). The electricity demand of the comminity requires a fu=l 
Input of 34,353 barrels of oil (206.1 $\times 10^{9}$ Btu) plus 7,960 tons or con (34,500 equivaleat barrels of oil or $207.0 \times 10^{9}$ Btu). This amounts to a total anmual fuel input of 67,155 barrels of ofl plus 7,960 tons of coal or 101,655 equivalent barrels of oil or $601.0 \times 10^{9}$ Btu.

ICFS Versus Conventional System Fue1 Use

A comparison of the three analyses shors the ICPS plant consuming sifgtly more ofl per year than the conventional alternatives and considerably less totel fuel.

The conventional oil-flred system consumes 4,610 barrels of oil (6 percent) less than the ICES plant. However, the conventional oil-fired system consumes 23,293 equivalent barrels of oil ( 32 percent) more than the ICES plant.

The conventional system with electric heat pumpe consumes 6,209 barrels of oil (9 percent) less than ICaS. However, the conventional system, utilizing electric heat putaps, consumes 28,269 equivalent barrels of oil (39 percent) wore than ICES.

The above information compares volume of affferent grades of oil. If the same comparison is made using the thermal content of the oil used, the results are as follors:

The conventionel ofl-fired systen consumes $15.3 \times 10^{9}$ Btu (4 percent) less all than ICES. However, the corventionel oil-fired system consumes $152.1 \times 10^{9}$ Btu ( 36 percent more) fuel than ICES.

The conventional system with electric heat pumps consumes $24.8 \times 10^{9} \mathrm{Btu}$ ( 6 percent) less oil than ICBS. Hovever, the conventional system with electric heat pumps consumes $-182.2 \times 10^{9}$ Btu (43 percent more fuel then ICES).

These dats are summerized grephicelly in Figures 10 and 11. 
FIGURE 10

FUEL COMPARISON: ICES VS. OIL HEATING

NOTE H: ICES REQUIRES 23,293 EQUIVALENT BBLS OF

0!L (152.1 $\times 10^{9}$ BTU) PER YEAR LESS THAN

THE CONVENTIONAL SYSTEM.

NOTE 2: ICES REQUIRES 4,610 B8LS OF OHL $\left(15.3 \times 10^{9}\right.$ BTU)

PER YEAR MORE THAA THE CONVENTIONAL SYSTEM.

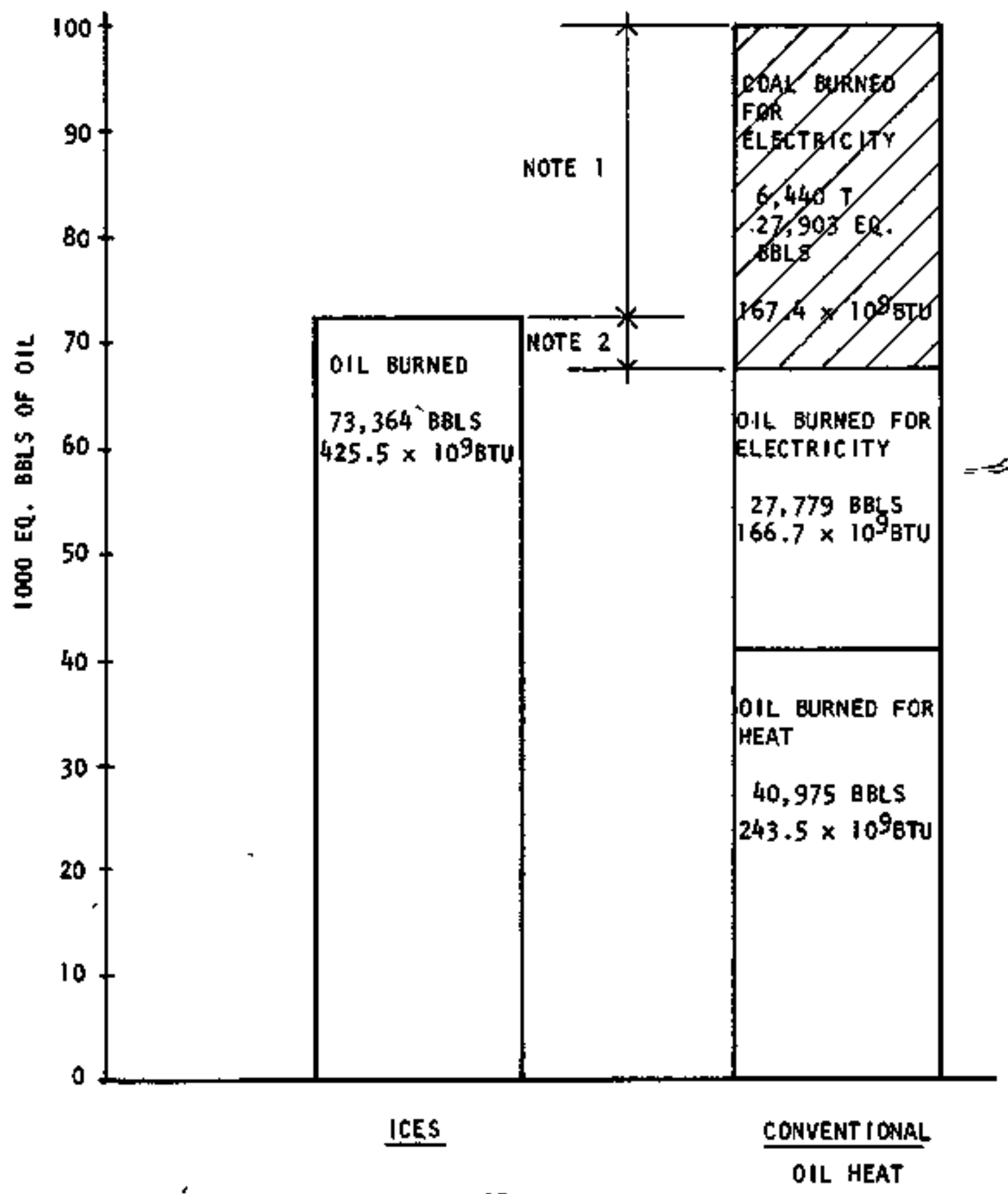


FIGURE 11

FUEL COMPARISON: . ICES VS. ELECTRIC HEAT PUMPS

Note 1: ICES REQUTRES 28,29I EQUIVALENT BBLS OF OIL $\left(182.2 \times 10^{9}\right.$ BTU) PER YEAR LESS THAN THE CONVENT 1ONAL SYSTEM.

Hote 2: ICES REQUIRES 6,209 BBLS OF OIL $\left(24.8 \times 10^{9}\right.$ BTU) PER YEAR MORE THAN THE CONVENTIONAL SYSTEM.

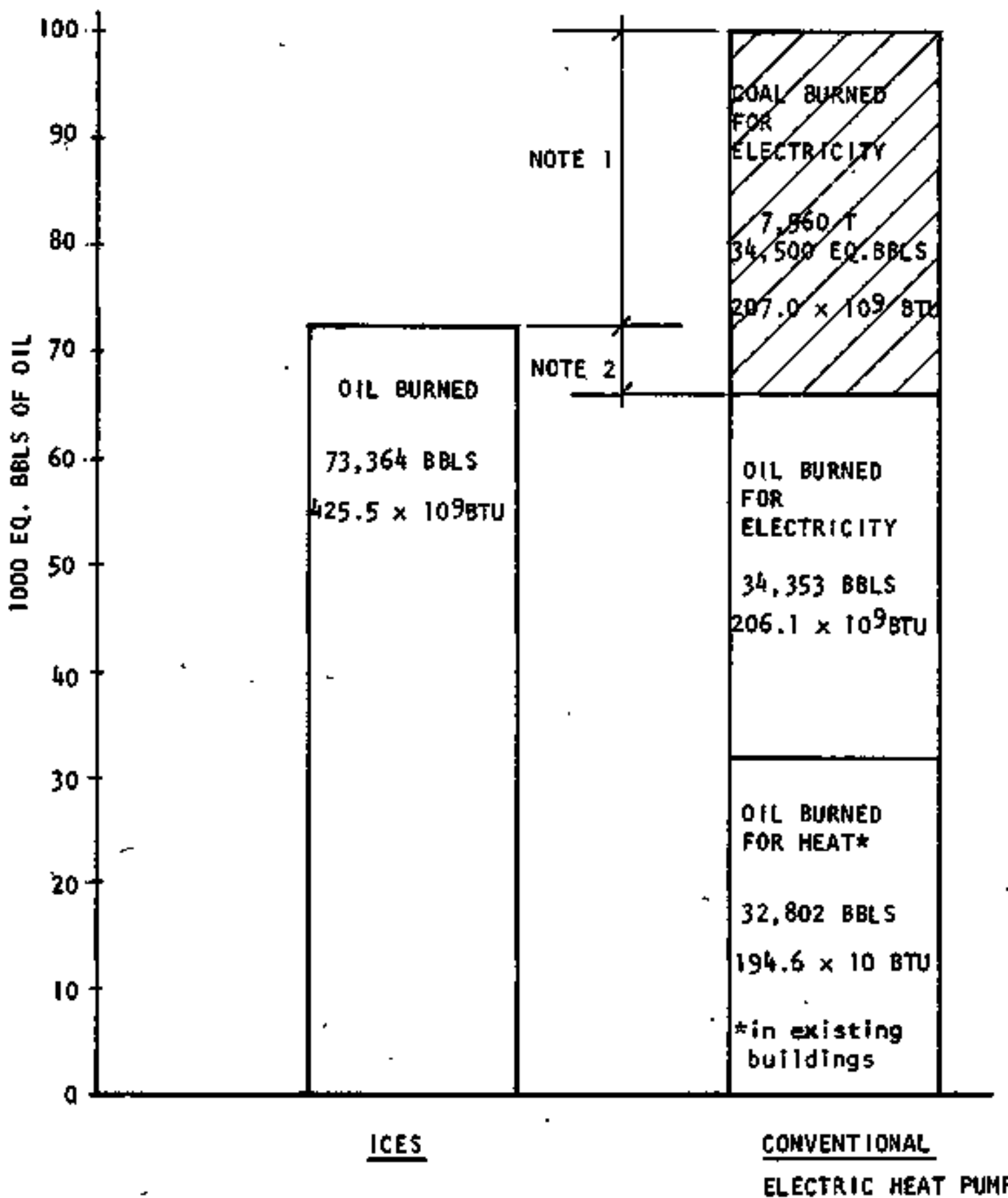




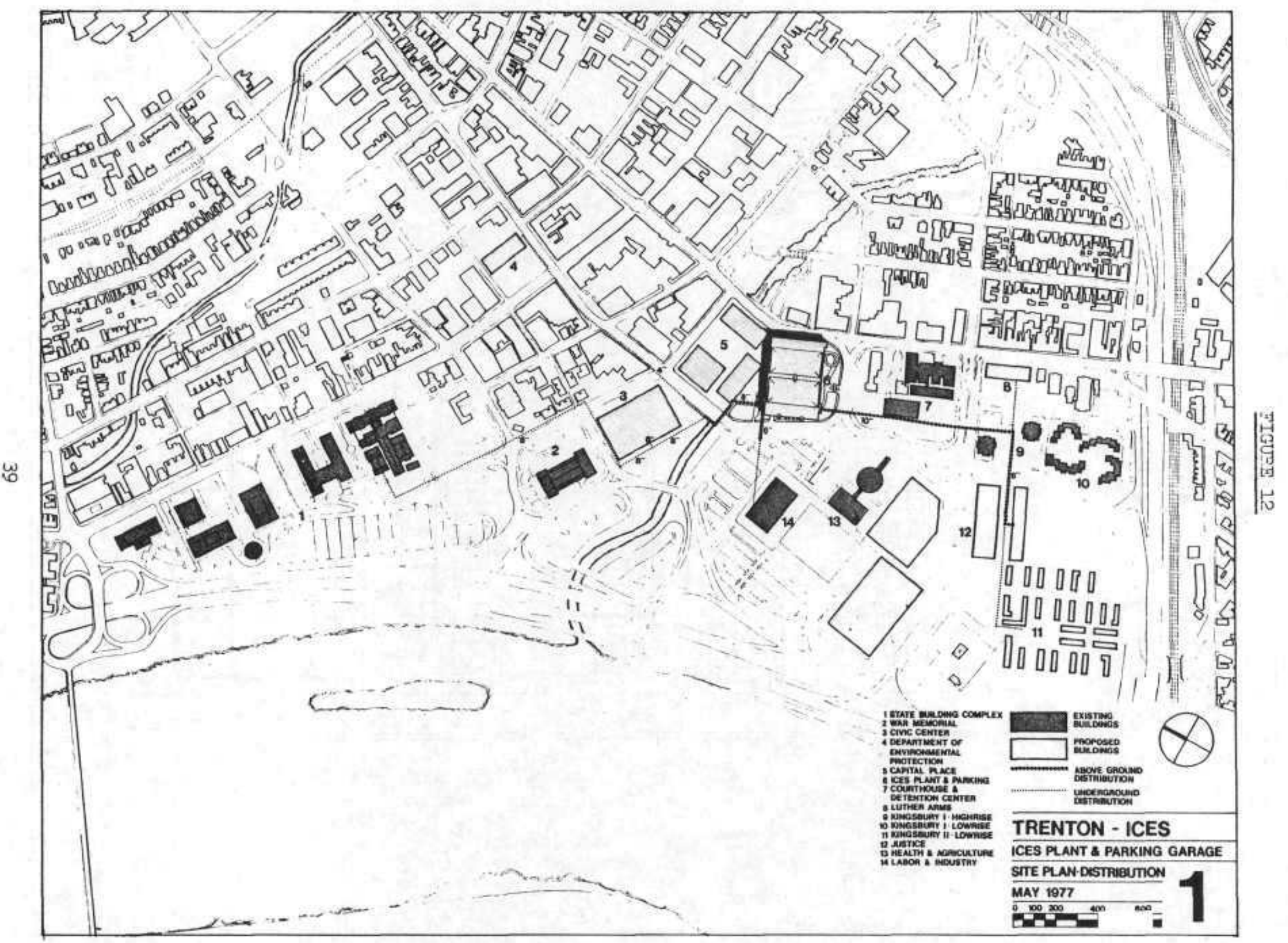




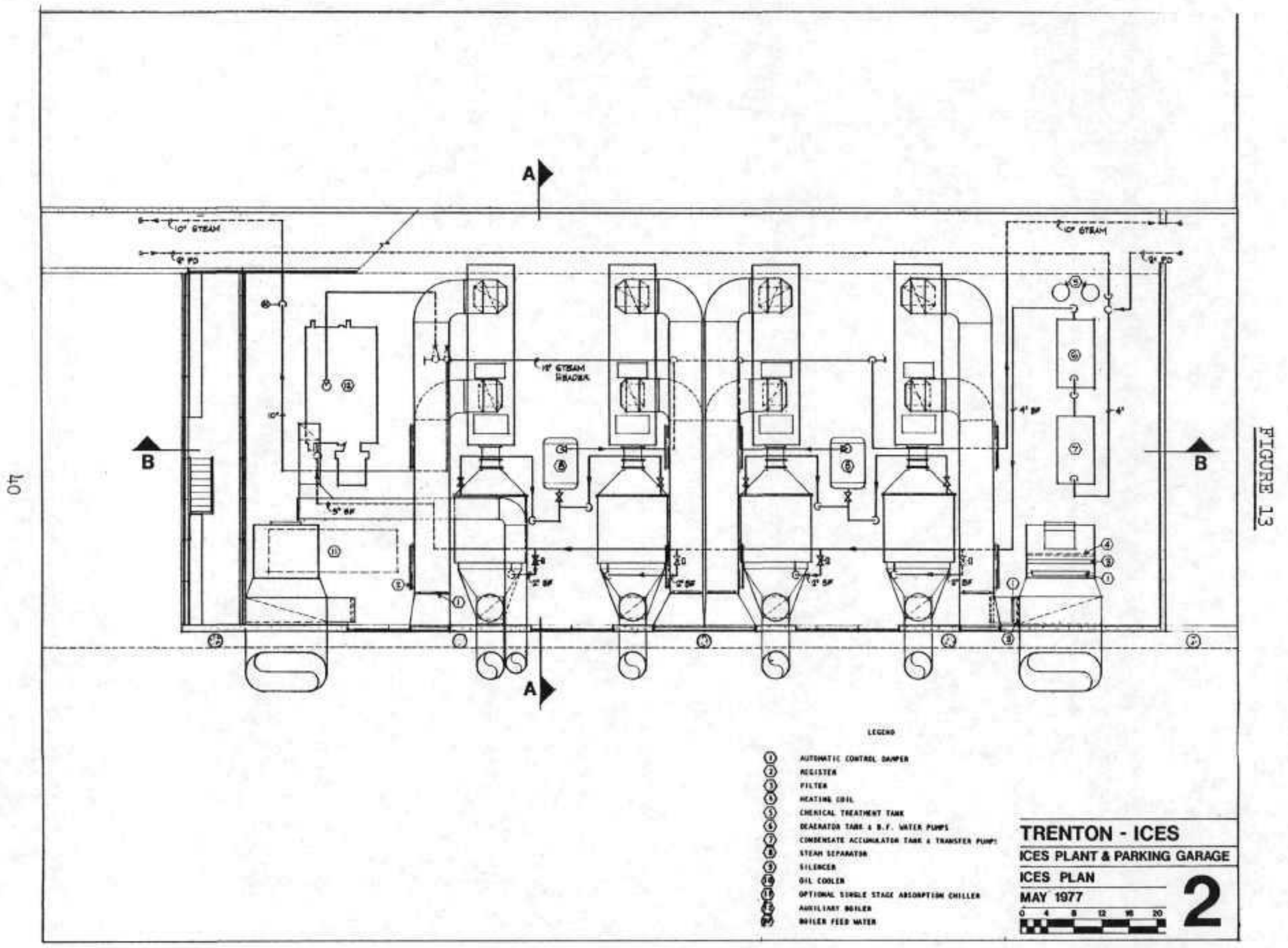




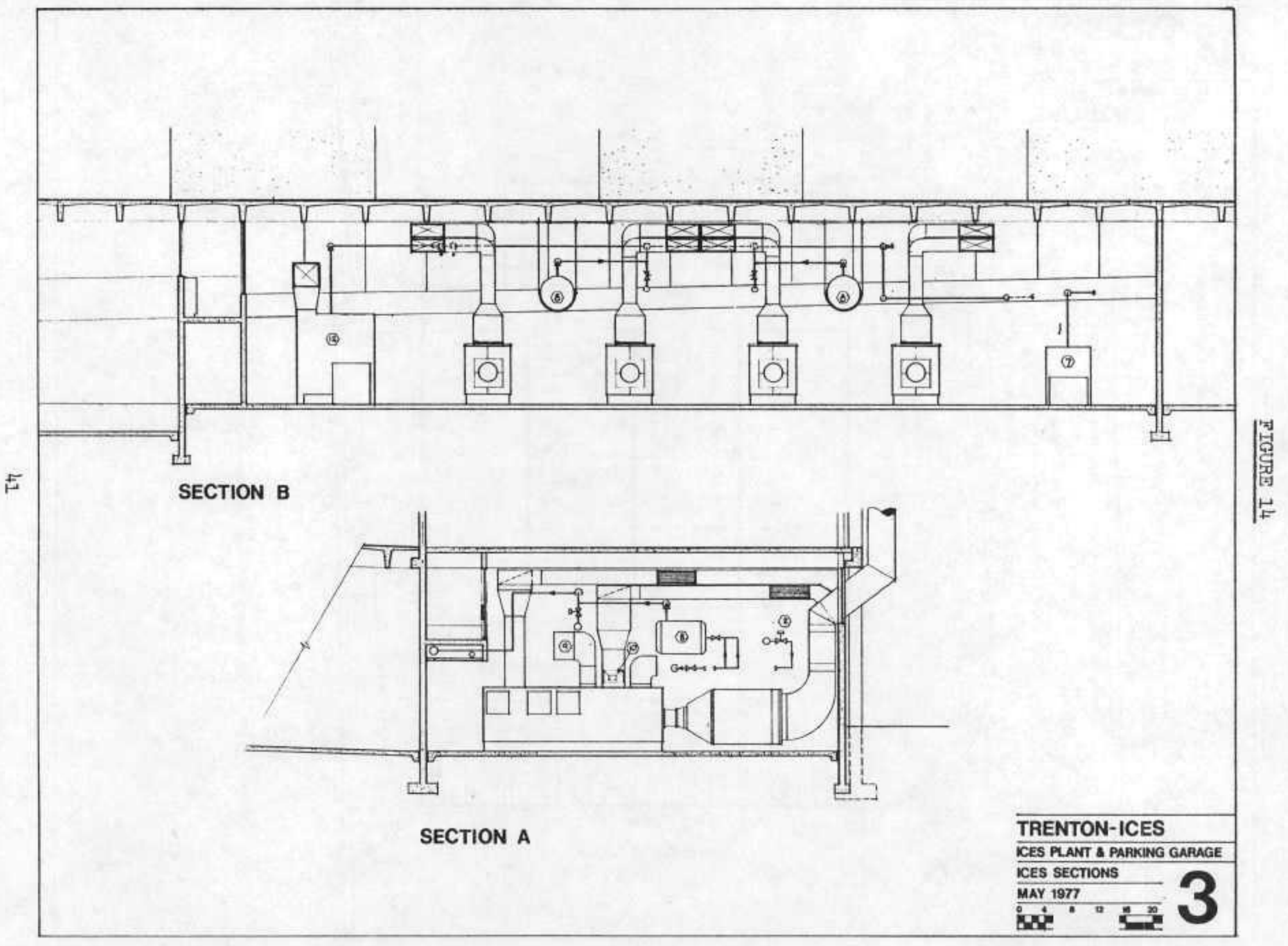




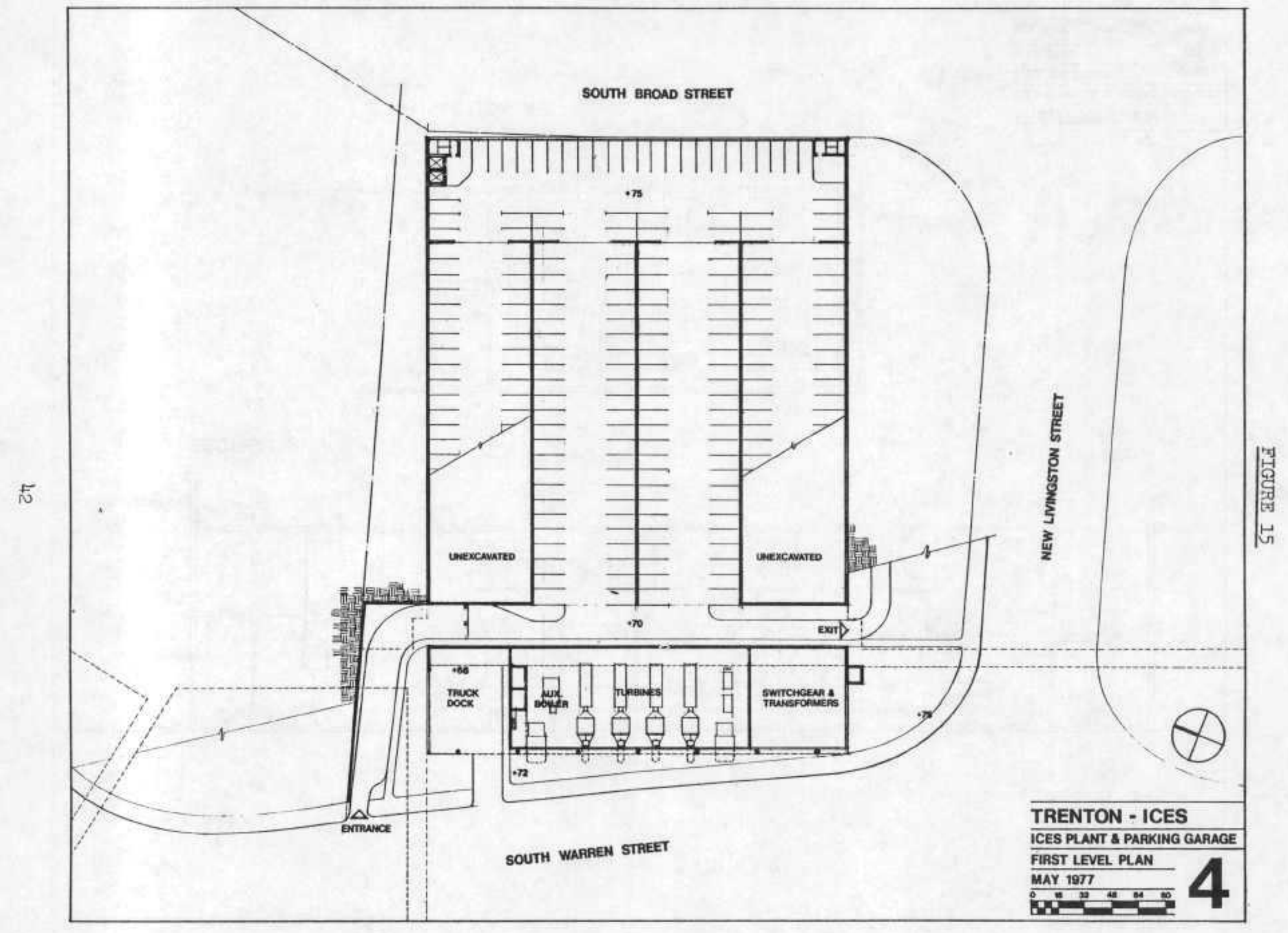




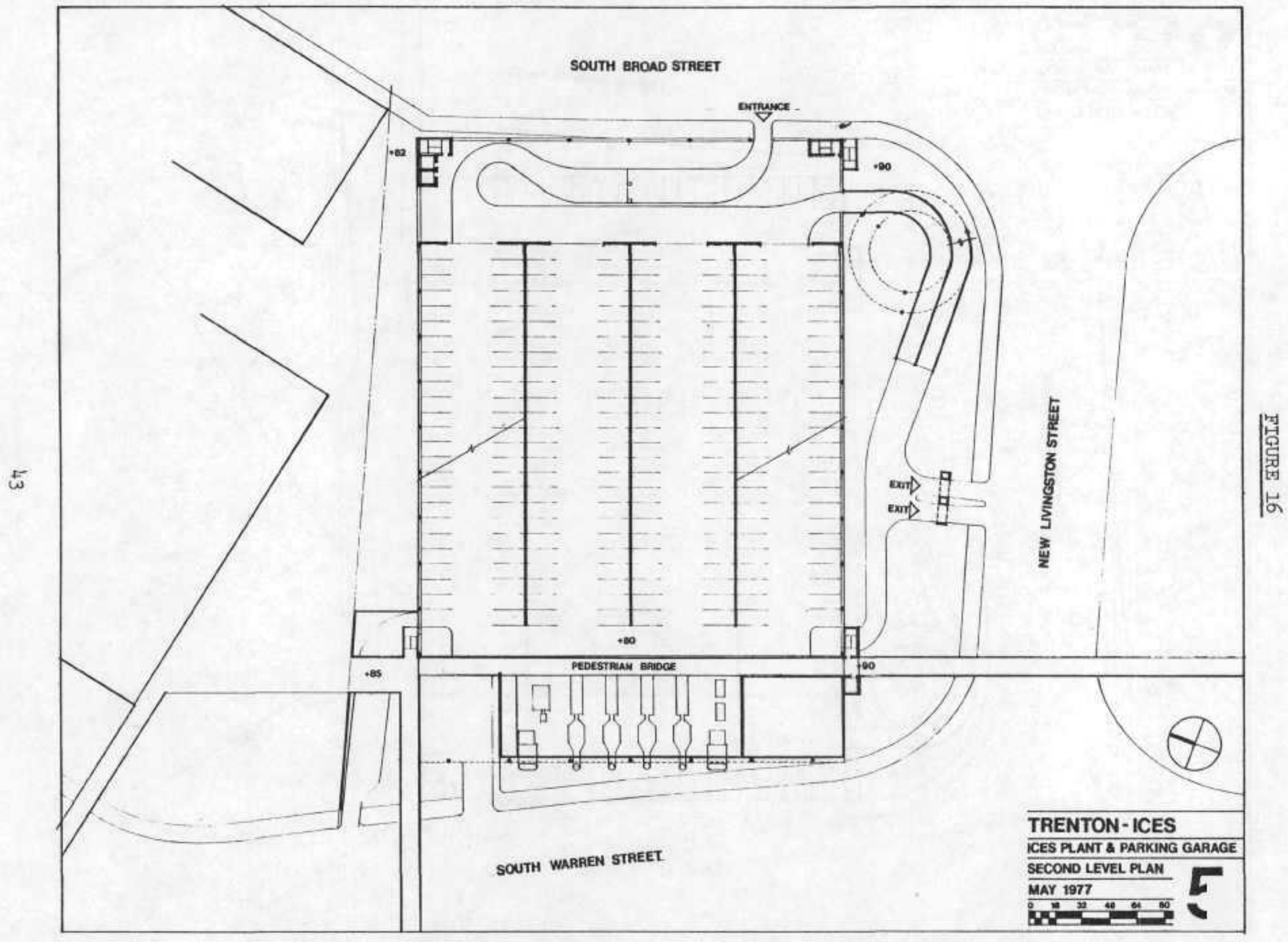




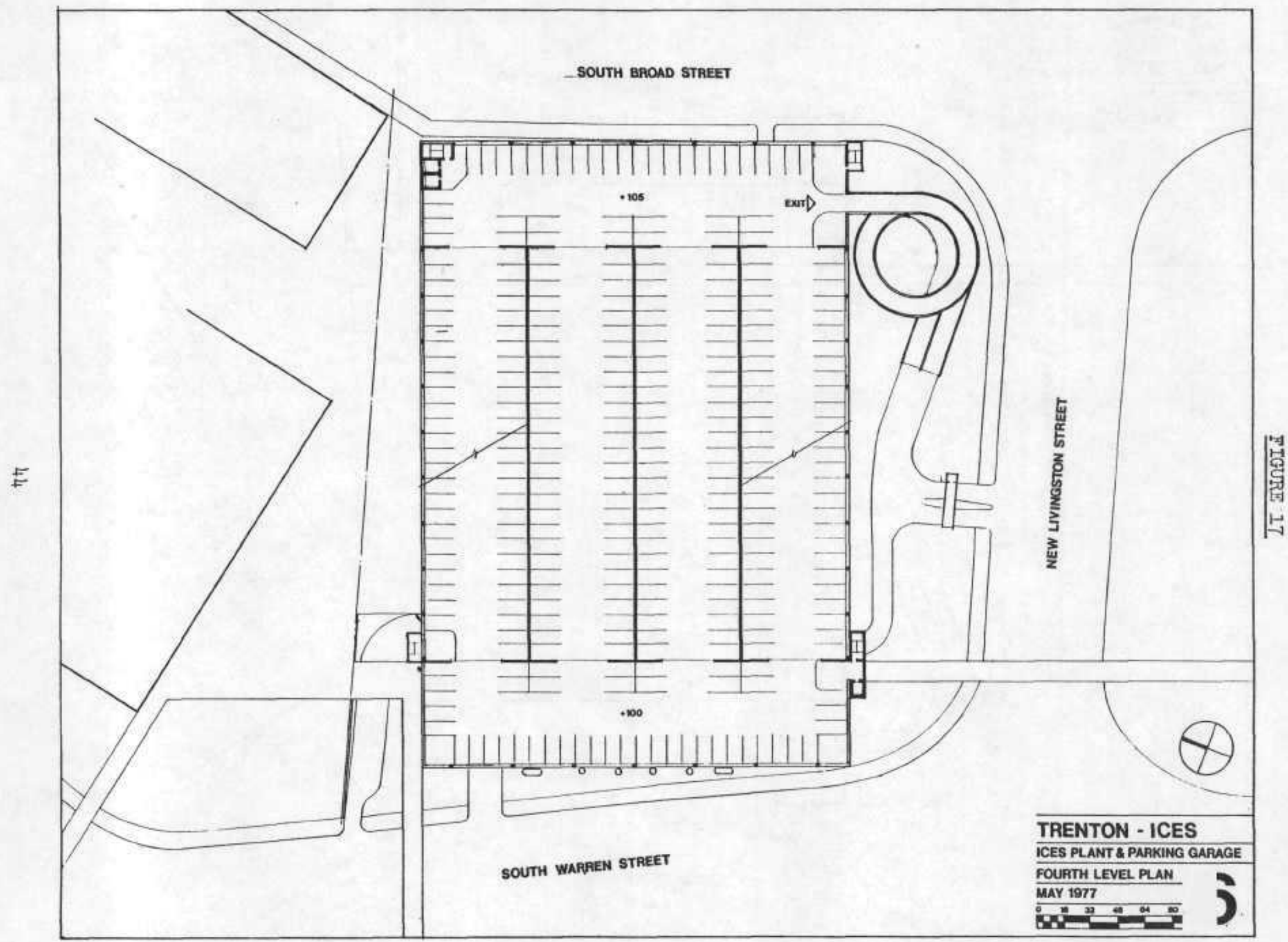




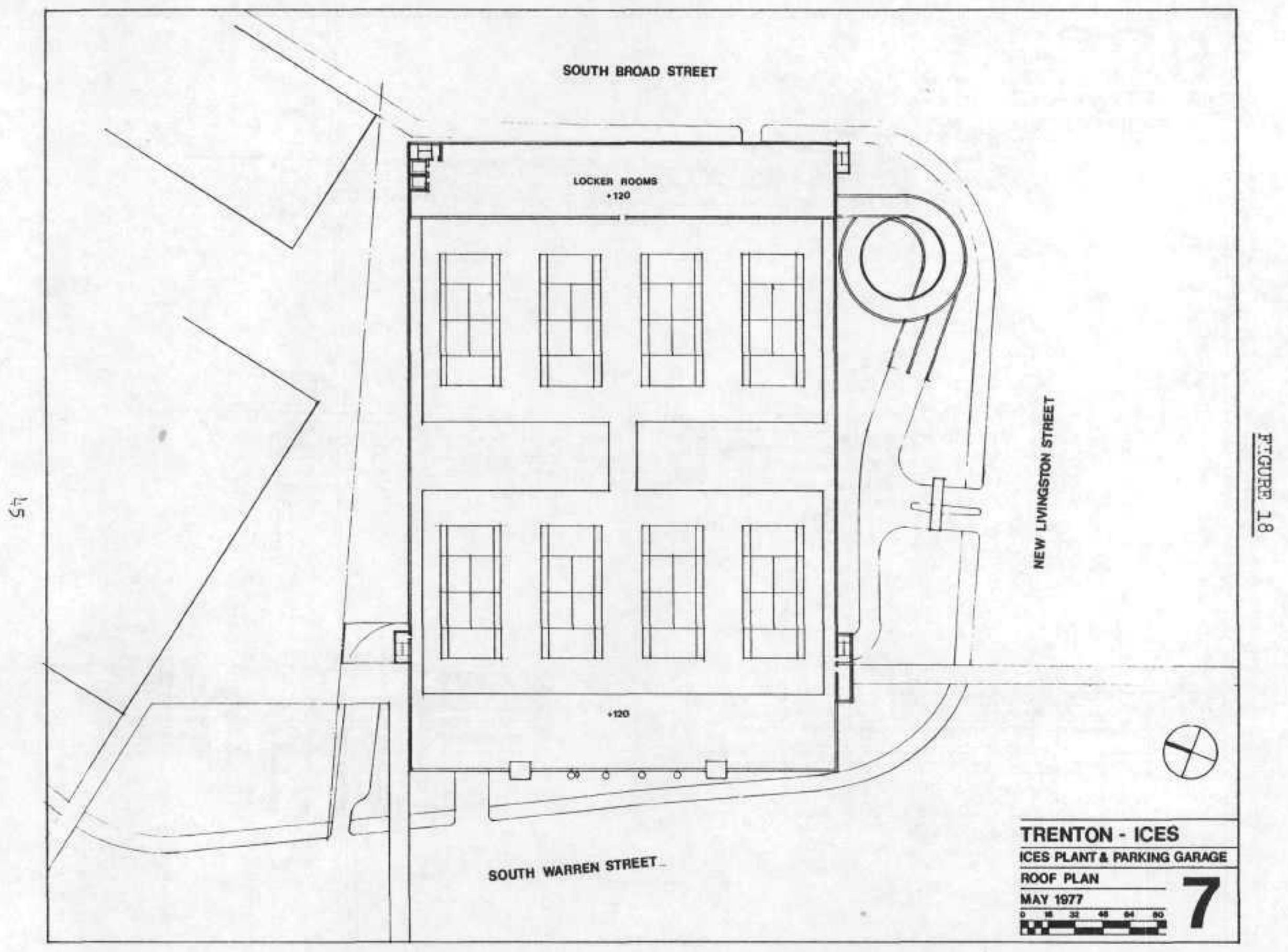




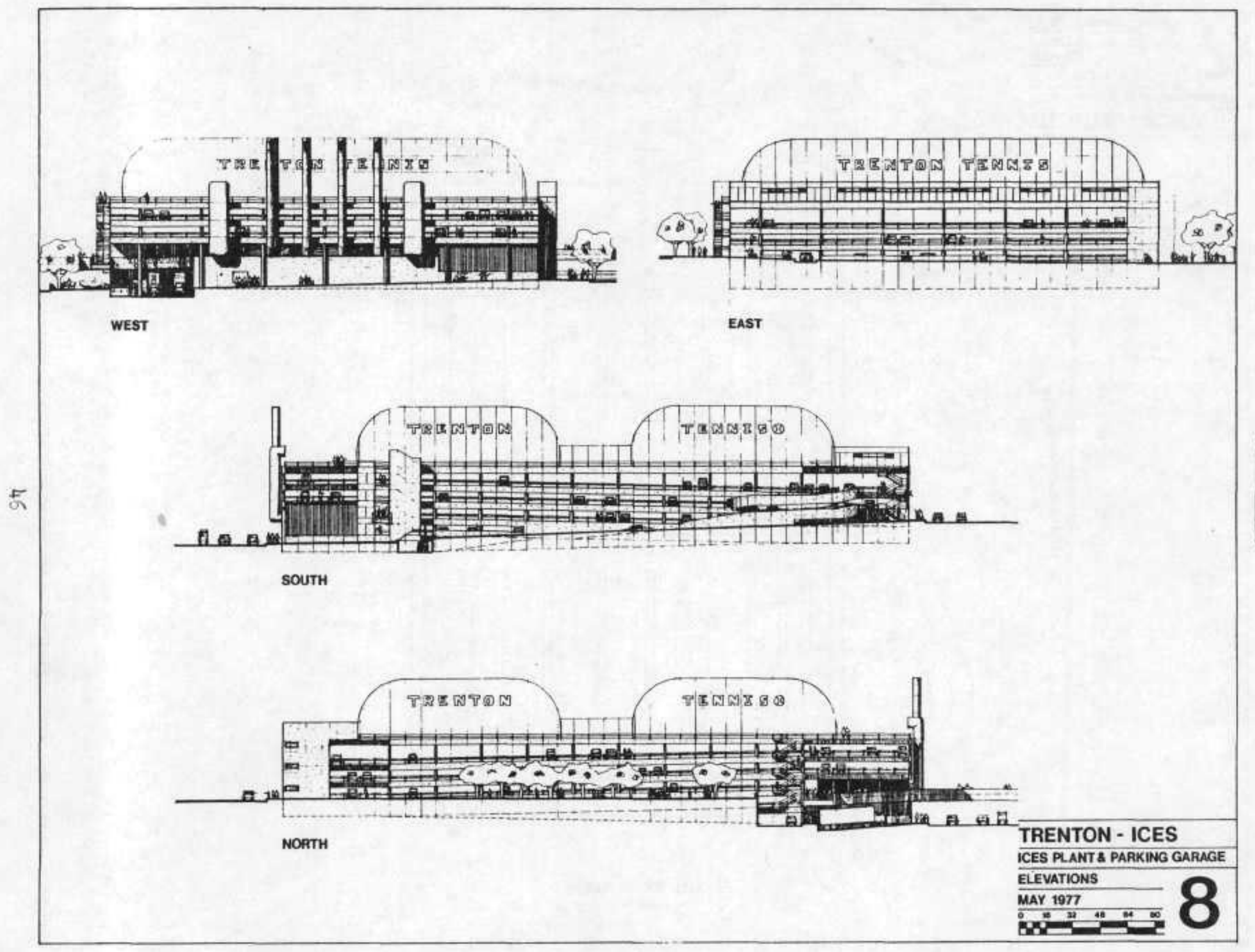




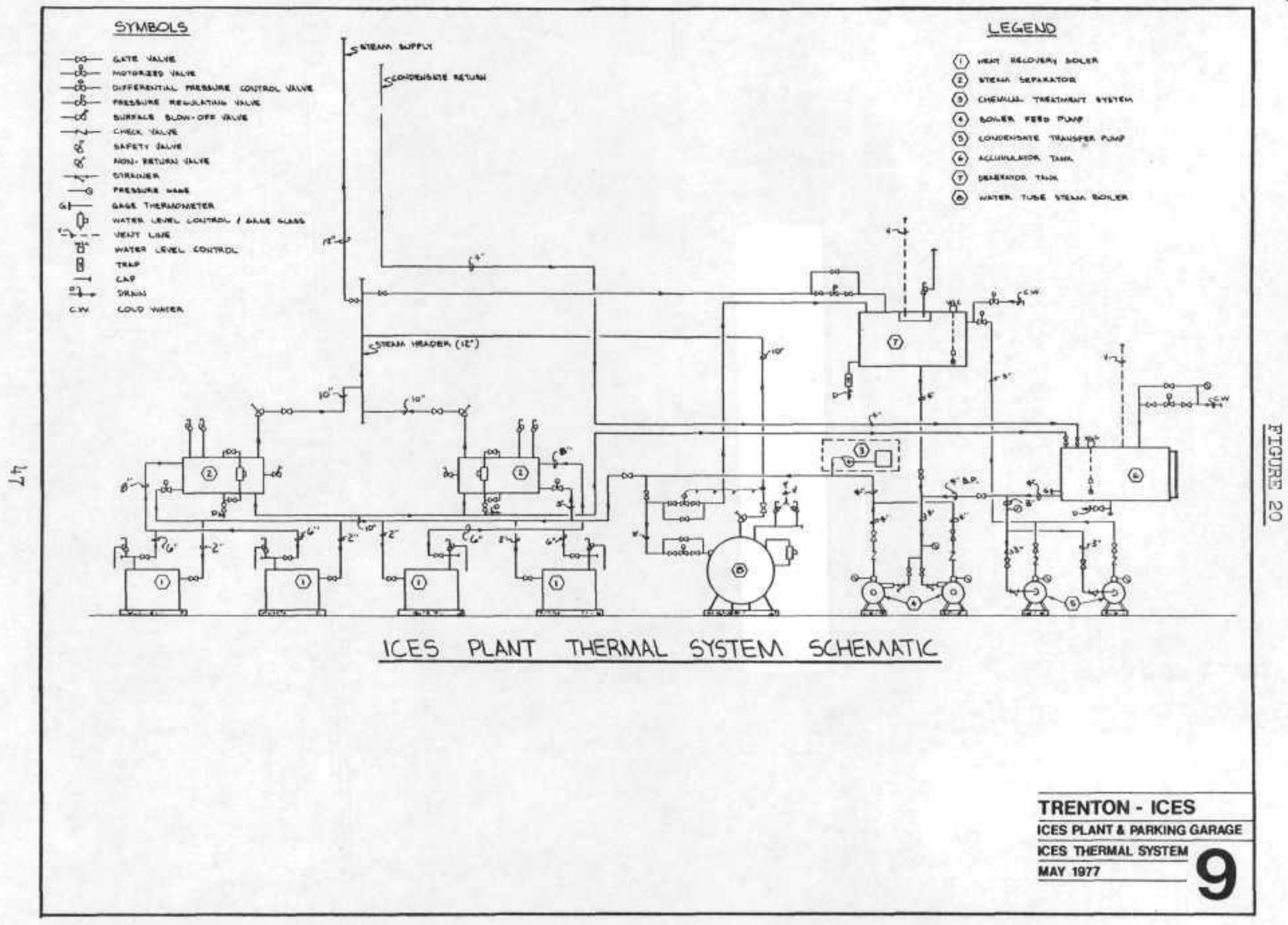


THIS PAGE

WAS INTENTIONALLY LEET BLANK 


\section{task IV}

firming up commitments 


\subsection{FIRMTNG UP COMITMERTS}

The Demonstration Team bas considered three areas where essential commitments must be made in order that the ICES aystem reach the 1uplementation stage. The flrst area is securing the comminents from the princlpal parties involved in the Demonstration Teat as to their continued particlpation in this Deomonstration Program. The second area is securing the commitment on the part of the customers to receive the service. The third sroup of commitments to be secured are those from the various regulatory agencies identifled in Task If Institutional Assessment.

\section{Demonstration Team}

All of the participants in the Demonstration Team are colmoltted to performing the Fhase II contract and are optimistic that the detailed feasibility study of Fhase II will confirm the preliminary feasibility anelysis which ahows that the Trenton ICES not only saves fuel but also will profide thermal energy to customers at a competitive cost while provlding Public Service Blectric and Gas Company a reasonable return on investment.

\section{Demonstrstion Communtty}

The Demonstration Team bas kept the observer-participants informed as the project has proceeded. An introductory working session was beId on February 16th, 1977 when representatives of the various ICES Demonstration Community owners attended a briefing session with the working menbers of the Demonstration Team.

Thege representatives, along with several other interested parties attended an executive sumary gession of the mid-term review with ㅍRA officials, hela on April 7th, 1977 at Irenton, Hev Jersey. Based on the preliminary feasibility study Fhase $I$, the Demonstration Conmunity customers have expressed enthusiasm about joining the system. 
Regulatory Bodies

¿

In order to secure initial review and commitment from the various regulatory agencies, the Demonstration Team contacted appropriate agencies to meet with them and to discuss the ICES concept, its epplication in dorntown Trenton, the ramifications to those agencies and their requirements for approvals. The following agencles were contacted:

1. The Hew Jersey Depertment of Environmental Protection

2. The Delavare Valley Regional Planning Commission

3. The Delaware fiver Basin Commission

4. The Hew Jersey Public Utility Commission

5. The Hew Jersey State Energy Office

6. The Trenton Planning Baerd

7. Hes Jersey Department of Labor and Industry, Hechanical Inspection Bureau

In each case the Demonstration Team found the regulatory agencies helprul in their suggestions and guidance in meeting their review requirements. No serious diffleulties were encountered at this prelininazr review stage.

\subsection{FTIANCIHG}

The Demonstration System will be owned and operated by Public Service glectric and Gas compary. As part of their large electric and gas utility system (third largest in the nation) the project would be financed by its normal process of issuing securities and using internally generated funds. However, the Demonstration Team recopnizes that in order to increase the margin of economic feasibility of this Deronstration Project and thereby insire its success, alternatit te means of Ilnancing which could lower the cost of money to PSE \& G will be explored. 


\subsection{FUER ALLOCATIOH}

At this time it is not possible to get a definite statement from the Foderal Energr Administration that ofl will be allocated to PSE \& $G$ for the ICES plant. Pregłdent Carter's energy message Indicates that electric utflities will be admonished to contert to coel there possible. Howerer, PSE G's experience in this area indicates that ofl will be readily available to fuel this plant. Since the fuel will be consumed so effleiently that it will conserve fossti ruel in the form of cosl for use elsewhere, the Demonstretion Tean feels confldent that there will be on adequate supply of fuel oil for this project.

Also, the present naturel gas supply situation would not allow PSS $G$ to use gaseous fuel for combustion turbine. However, if additional gas supplies could be made aveilable from new sources such as Atiantic off-ghore drilling, coal gasification, etc, then gas may be considered as a viable future fuel supply for the ICES plant in order to conserve oil.

With minor modifications, combustion turbires can be converted to burd either oil or gas.

\subsection{OWNERSHIP AID OPERATION}

The Trenton ICES Demonstration Project will be owned and operated by Public Service Electric and Gas Company as part of the overall power generation system of PSE \& and the Pennsyl vanie-New JerseyMaryland (P-J-M) Intercannection Power Pool. PSE \& G will operate the system in response to thermal demend in accordance with the ICDS concept with the possible exception of an emergency situation when all other PSE G and F-J-W peaking generators are or Iine and additional electrical system demand mugt be met on a short term basis. 


\subsection{CUSTOHER IHDUCBMATS}

\section{Dectsion Process}

Choles for energy supply to building for use in beating, ventilating and air conditioning (HVAC) System ere usuelly based on one or more of the following paraneters:

1. Capital cost of the system

2. Fuel Cost and Availability

3. Life of Equfpment

4. Ease of Malntenance and Complexity of the System

5. Operating and Maítenance Expenses ( $O$ \& $)$

6. Relisbility, notse, aesthetics, ease of control, etc.

The interaction of these parameters impats on the building owners' dectsion process baged on yet another kroup of parameters.

1. Hot is the capital generated? Is capital money more easily obteined then operating subsidies?

2. Does the ouner also operate the system?

3. Does the ower/operator have a more favoreble invegtment alternative avaliable to hire? (e.g. another apartment rather than an expensive IVAC System)

4. What is the estimated life of the project?

5. What is the total cash flow of the project and whet percentage does the HVAC aIterative represent?

With some variations, decisions regarding gVAC Systems and their energ auply are based on a liforcycle cost anolysis. Using this approach, the capital, $0 \& \mathrm{H}$ and energ costs are eralueted for 
avalable fuels using the estimated life of the project. The alternative which yields the lowest present worth of all future costs is usually chosen. The difference between alternatives, must, however, be significant enough to off-set or override the other parameters mentioned above.

\section{Exdsting Eutlatngs}

For the existing buildings, the deciston will be made using a comparison between the customer's present energy supply and associated costs and the conversion operating, maintenance and thermal costs of an ICES system. The two most sensitive areas in this analysis are the cepital conversion costs, and the thermal costs including contract duration, minimin charges and termination costs.

\section{New Buildings}

For the new buildings, a much more edvantageous economic position is possible for ICDS due to the complete capital anortization of both terminel systeris. In this esse, thermal costs slone are the most sensitize area.

In addition, some members of the Demonstretion Community may find social and political adrantages to becoming part of ICES. Trenton ICES would be looked on as a first of its kind and is a visible symbol of energy saving. Both of these aspects are newsworthy.

\section{Inducements}

With an eye towards customer inducement, the ICDS project tean Imust develop steam rates or contracts which vill sccomplish the following: 
1. Offer tome margin of life cycle cost advantage over conventional systems.

2. Encourage summer and winter use of thermal energy consistent with user needs.

In addition, the use of a non-restrictive policy must be evaluated and established regarding the conversion costs for exiating buildings. 
task V

work management plan 


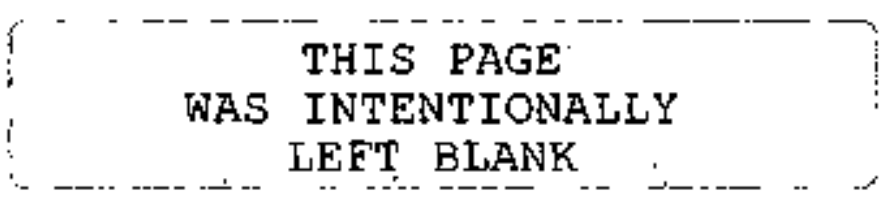

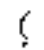




\subsection{SCHEDULIFG REQUTRTMENTIS}

In order to meet the stringent time requirements necessary for the Demonstration system to be on line when the first new portions of the Demonstration Community are constructed, an aggressive time schedule has been established.

Capital Place I will be ready for occupancy in May 1979, therefore the Work Managenent Plan consists of a two-tiered fast track approach. The Demonstration System must have thermal capacity avallable by Ming 1979; this means that the plent eaclosure including the parking garage for which it is an intergral part by the nature of its urban design), the back-up boiler system and the first portion of its distribution system mist be completed by that date. We have therefore established two stages of construction for the Demorstration System: StaBe "A" which consists of the back-up boiler (used to provide steam to Capital Place I, Luther Arms and the Justice Complex until the turbines-generatozs and waste heat boilers are on line), the portion of the distribution system serving Capitol Place $I$, the Mercer County Detention Center-Courthouge Complex, Kingsbury I, Luther Arms and the Justles Complex, and the plent enclosure including the parking garage; and Stage "B" which consists of the electrical generation and waste heat recspture gystems, controls, etc, and the remeinder of the steam distribution network, and the electrical interconnection with the Utility orid. 


\subsection{WORK MAMAGRITHF: PHASE II}

\section{Task I Energr Anglyg is}

A. Reassessment of Phase I Work

1. Reassess Demonstration Community and modify energy proriles.

2. Investigate possible use of cosl technology as a retroft Including on-site coal gasification and/or use of PSE \& $G$ multiple-source gas supply including coal gasiflcetion.

3. Assess future growth of community.

B. Further Investigation of Economic Parameters

1. Investigate module size for potential incremental growth of the Demonstration System.

2. Develop demand profiles year by year as the Demonstration Community develops.

3. Investigate alternate desifgs for the ICES plant enclosure.

4. Reassess ICES economics including a sensitivity analysis based on variations of significant perameters.

Task II Institutionel Assessment

A. Development of draft forms of agreement where necessary:

1. Urban renewal parcel land disposition

2. Easements and rights-of-way for thermal distribution and storgo fecilities

3. Customer service agroements

B. Preliminary approval of oil allocation from the U.S. Federal Bnerg Administration.

C. Amendment of the John Fitch Way Urban Renewal Plan.

D. Evaluation of alternative floancins errangements. 
E. Draft environmental assessment.

F. Deterinination of PSE \& G 5 tean service policy.

1. Service application procedures

2. Inspection of customer's facilities

3. Service additions and alterations

4. Access to customer's premises

5. Metering and aervice conflguration

G. Determination of steant rate pollcy

H. Analyze the effect of building the ICSS Demonstration Bystem.

1. PSE \& G: financial analysis

2. Each customer: life cycie cost study

3. City of Trenton: tax benerit analysis

Task III Prelimfinary Endneering Destign

A. Preliminary design of power and thermal systems, subsystems and controls.

B. Prelininary degibn of gteam distribution and thermal storage systems.

c. Preliminary design of the ICDS plent enclosure including the elevated wailkways.

Task IV Final Engineering Desien of the Stage "A" Construction Including Construction Documentation

A. Final engineering and architectural design of the 'stanaby boiler (which will provide thermal service until the entlre Demonstration System is operable) the ICES plant enclosure, and the Stage "A" therwal distribution and storege network to serve Capital Place I, the Hercer County Detention Center and Courthouse, Kingebury I, Luther Arms and the Hew Jersey state Justice Complex. 
Tesk $\mathrm{y}$ Customer Limisog

A. Dsteblishment of contect with the necessary operating and mansgoment pergonnel for esch member of the Demonstration Community.

B. Wtafn any necessary finel commitments end arrange for customers to allow IRDA to conduct end use tests. Determine final financial gtatus of each customer.

5.3 WORK MARAGEMEHT: PHASE III

Task I Finel Degi mand Construction Documentation

A. Final desion and construction documentation of power and therasel systems, subsystems, components and controls.

B. Finel desion and documentation of thermal datribution and storage systems.

Task II Construction of the Stage "A" Demonstration System

A. Receive bids end/or negotiate construction contracts and corstruct the Stage "A" Demonstration Bystem as described in Fhase II, Task IV above.

Task III Operation and Meintenance Procédures

A. Prepare detailed operstions and mantenance procedure manual.

Tesk IV Customer tiatson

A. Continue cutomer lieison to define customer's requirements for end-use equipment and metering.

\subsection{WORK MAHAGEMERT: PHASE TV}

Task I Construction Managenent

A. Freconstruction planning and actirities plus menagement of the construction process. 
Tesk II Construction

A. Perform the renglning construction to complete the ICBS system.

Task III Customer Liaison

A. Continuation of customer liaison to coordinate service connection.

Task Iy Billing Prosedure

A. Bstablishment of meter reading and billing procedures.

B. Train appropriate customer accounts personnel.

\subsection{WORK MAMAGEMSTI: PHASE $\mathrm{V}$}

Task I Srstem Instailation Tests

A. Testing to terify that the equipment installations have been made In accordance with the construction documents.

Task II Start-th Tests

A. Preparation of schedule or start-ip tests.

B. Conduct Start-up Teats with U.S. ERDA concurrence.

Task III Installstion of Monitoring Equipment

A. Deglgn and Installation of Moultoring Instrumentation Systems

(MIS) for detailed deta collection.

Tasik IV Performance Test

A. Frovdde for and perforw a j-year performance test of the ICES Demonstration system.

Task $v$ Customer Liajson

A. Continued customer liaison to asture proper comminicetions and biliing. 


\subsection{WORK MATAGEMIIT: PHASE VI}

Task I Qperation and Maintenance Management

A. Operation and baintenance of the Demonstration System according to the schedule established in Fhase III, Task III above.

\section{Task II Iong Term Demonstration Evaluation}

A. Preparstion of reports to evaluate the Demonstration System.

\section{Task III Post Contract Operation}

A. Preparation of a post contract program plan for the continued operation of the Demonstration System.

Tasks IV Custorier Lialson

A. Continustion of on-going custower liaiaon program.

\subsection{DENOMSTRATION COST ESTIMATES*}

\section{BOA-CONSTFUCTIOH DEYONSTRATEOR COSTS}

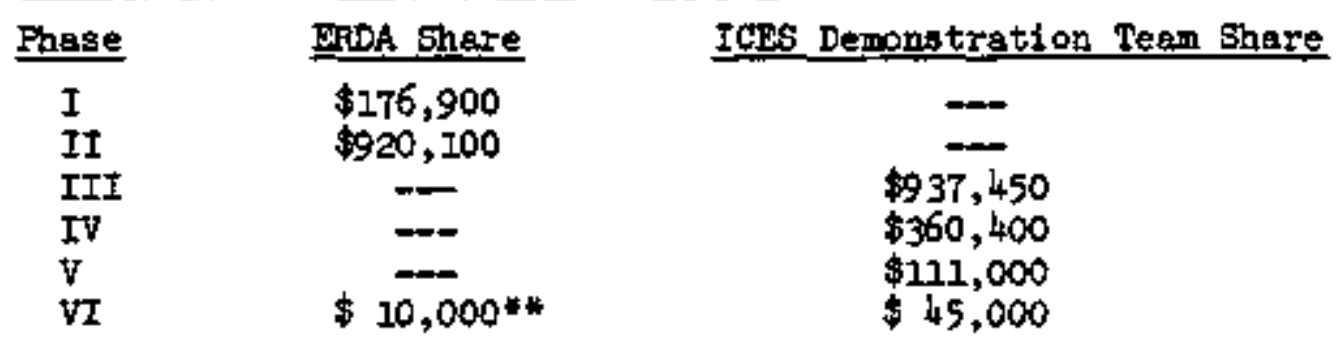

\section{CORSTRUCTION COSTS}

Fhose

I

II

III

IV

$\mathrm{V}$

VI
ERDA STare

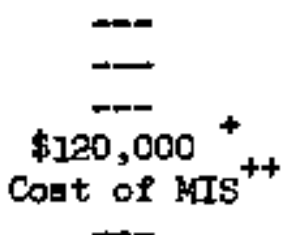

ICES Team Share

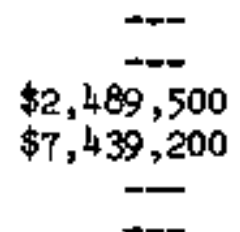

* Hote: All costs in 1977 dollars.

** Coste to very with the reportin

+ Fossible BRDA subsid to exiating builaings for capital coats of connection to the Demonstration System, if the Iew Jersey Public Utilities Commission vill not permit differential steam contract rates for new and existing construction.

+ Monitoring Instrumentation Syatems as required by BRDA or the . Fational Bureaz of Standards. 


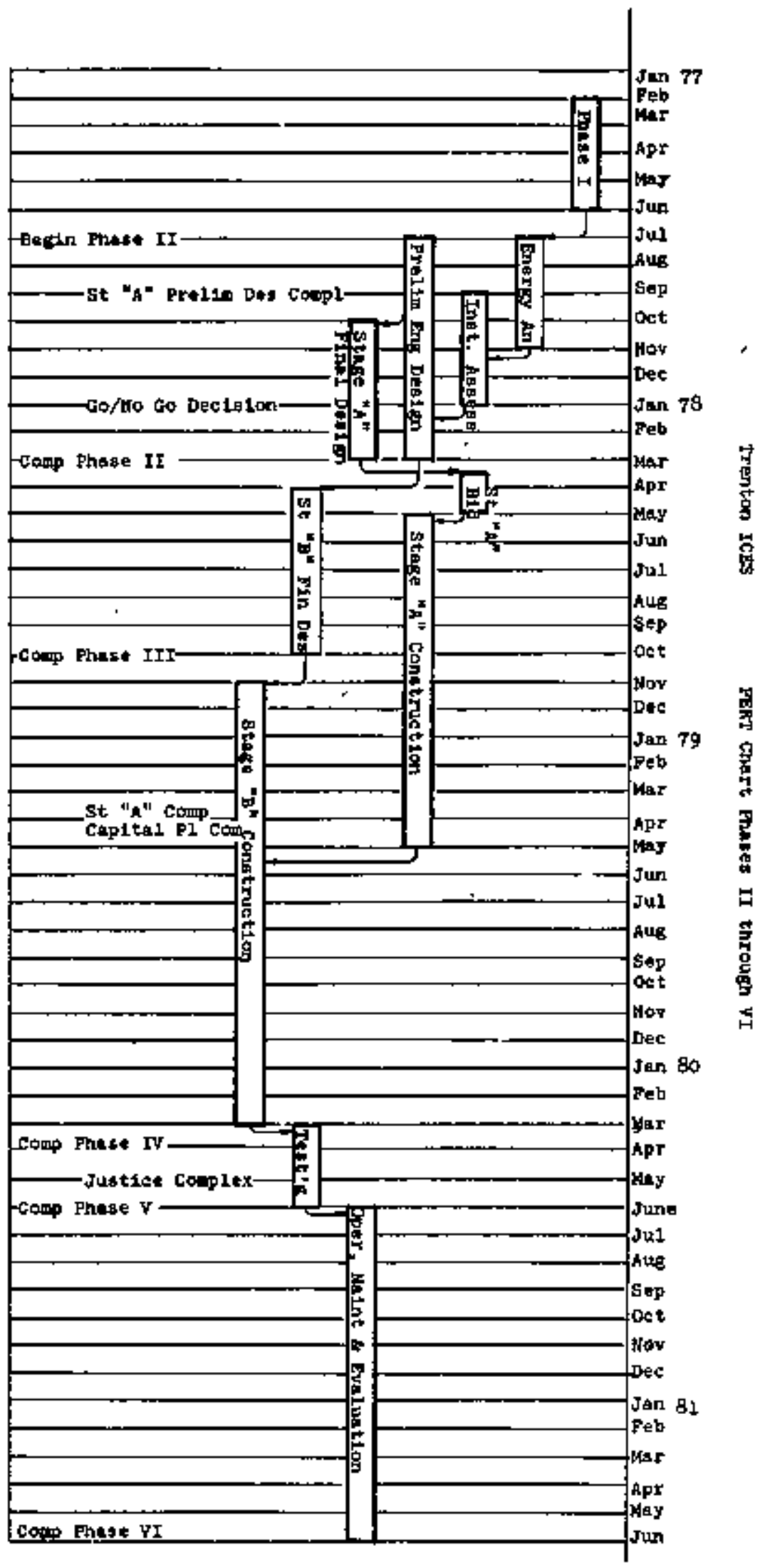


FIGURE 22

5.9 DEMONSTRATTON TEAM ORGAHIZATION

Trenton ICES

DEMONSTRATION TERM G. IN! IONAL

CHARTS. :ASE II ANU :HASES III - VI

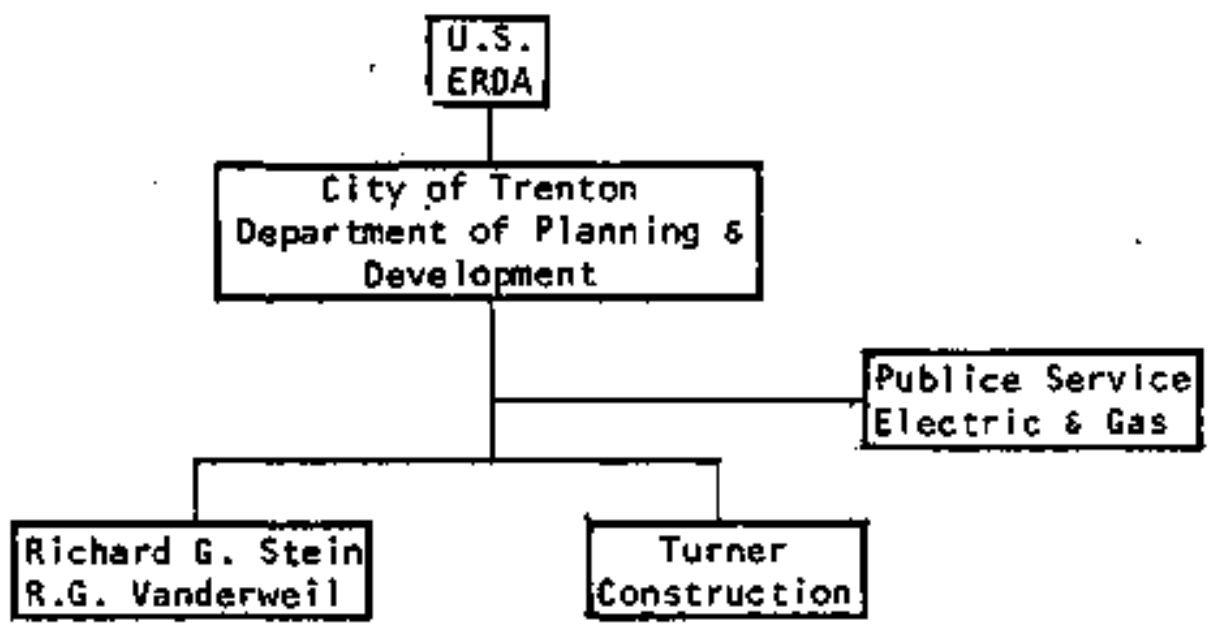

PHASE II DETAILED FEASIGILITY AND

PRELIMINARY DESIGN

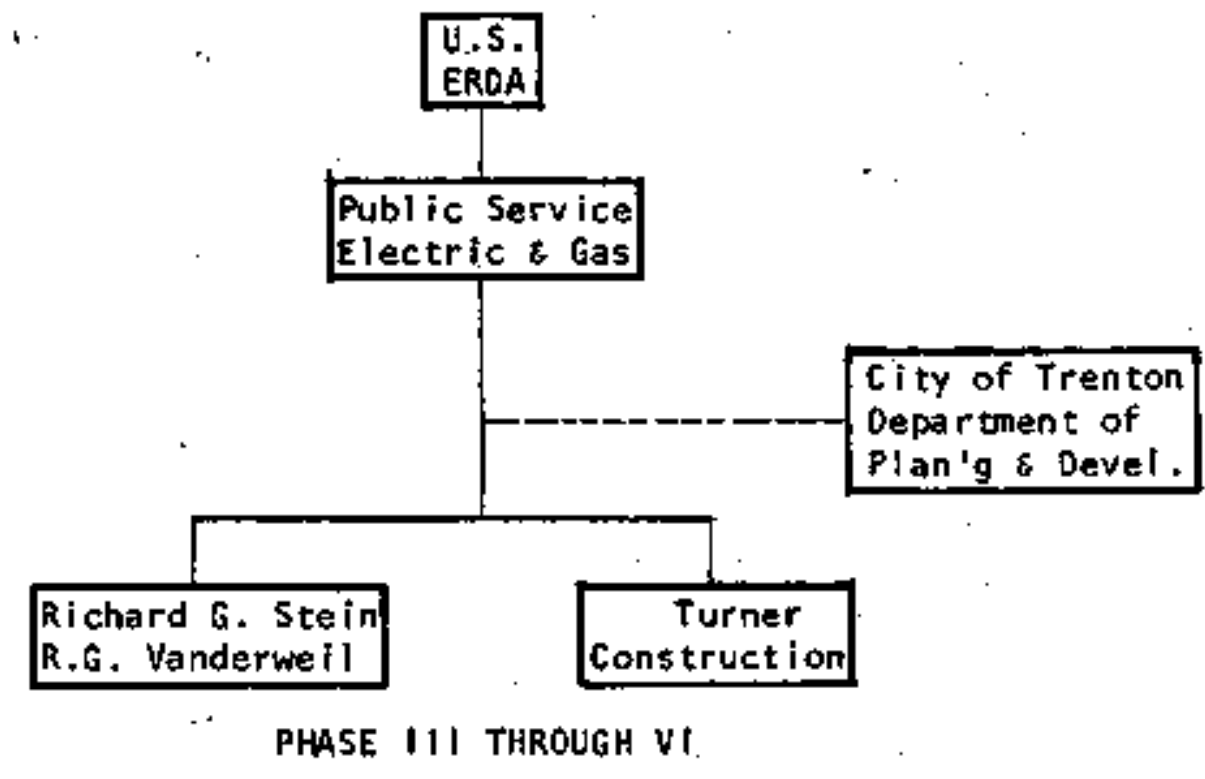

